Article

\title{
Origin of Warm SST Bias over the Atlantic Cold Tongue in the Coupled Climate Model FGOALS-g2
}

\author{
Yanyan Shi ${ }^{1,2}$, Wenyu Huang ${ }^{1, *(1)}$, Bin Wang ${ }^{1,3}$, Zifan Yang ${ }^{1}$, Xinsheng $\mathrm{He}^{1}$ and Tianpei Qiu ${ }^{1}$ \\ 1 Ministry of Education Key Laboratory for Earth System Modeling, and Department of Earth System Science, \\ Tsinghua University, Beijing 100084, China; shi-yy12@mails.tsinghua.edu.cn (Y.S.); \\ wab@mail.tsinghua.edu.cn (B.W.); yzf15@mails.tsinghua.edu.cn (Z.Y.); hexs16@mails.tsinghua.edu.cn (X.H.); \\ qtp17@mails.tsinghua.edu.cn (T.Q.) \\ 2 School of Environment, Tsinghua University, Beijing 100084, China \\ 3 State Key Laboratory of Numerical Modeling for Atmospheric Sciences and Geophysical Fluid \\ Dynamics (LASG), Institute of Atmospheric Physics, Chinese Academy of Sciences, Beijing 100029, China \\ * Correspondence: huangwenyu@mail.tsinghua.edu.cn
}

Received: 20 June 2018; Accepted: 16 July 2018; Published: 18 July 2018

check for updates

\begin{abstract}
Most of the coupled models contain a strong warm bias in sea surface temperature (SST) over the Atlantic Cold Tongue (ACT) region $\left(10^{\circ} \mathrm{S}-3^{\circ} \mathrm{N}, 20^{\circ} \mathrm{W}-10^{\circ} \mathrm{E}\right)$ during June-August (JJA) and September-November (SON). In this study, the origins of the ACT SST bias and their relative contributions to the bias are explored by conducting a set of sensitivity experiments, which are based on an ocean-ice model, and by ignoring the nonlinear effects of each origin. The origins for the warm bias over the ACT in the coupled climate model during JJA are estimated as follows: westerly wind bias along the equator $\left(5^{\circ} \mathrm{S}-5^{\circ} \mathrm{N}\right)$ during March-May (MAM; contributes approximately $32.6 \%$ of the warm bias), northerly bias over the southern tropical Atlantic $\left(25^{\circ} \mathrm{S}-3^{\circ} \mathrm{N}, 40^{\circ} \mathrm{W}-20^{\circ} \mathrm{E}\right)$ during MAM and JJA (21.4\%), bias in the surface specific humidity and surface air temperature $(11.9 \%)$, and downward shortwave radiation bias (6.5\%). The origins of the ACT bias during SON are as follows: northerly bias over the southern tropical Atlantic during SON (31.2\%), bias in the surface specific humidity and surface air temperature (27.9\%), downward shortwave radiation bias $(17.4 \%)$, and zonal wind bias (13.4\%). Note that these contribution ratios of these origins may be model-dependent. In addition, the local and non-local effects of the zonal wind bias are explored explicitly, while those of all the other biases are examined implicitly. Therefore, a better-performing atmospheric component is crucial when simulating zonal winds during MAM along the equator $\left(5^{\circ} \mathrm{S}-5^{\circ} \mathrm{N}\right)$ and meridional winds during MAM, JJA, and SON over the southern tropical Atlantic, which will alleviate the warm bias over the ACT region in the coupled climate model.
\end{abstract}

Keywords: origin; warm SST bias; Atlantic cold tongue; FGOALS-g2

\section{Introduction}

Most of the coupled climate models (CCMs) show a severe warm sea surface temperature (SST) bias for the tropical Atlantic [1-5]. In the southeastern tropical Atlantic (SETA) region $\left(25^{\circ} \mathrm{S}-10^{\circ} \mathrm{S}\right.$, $\left.10^{\circ} \mathrm{W}-15^{\circ} \mathrm{E}\right)$, the warm SST bias is mainly concentrated in the Angola-Benguela Frontal Zone [3,6-12] (ABFZ) with a magnitude that exceeds $5{ }^{\circ} \mathrm{C}$ (IPCC 2013). The origins of the warm bias over the ABFZ have already been attributed to both local sources $[4,5,9-11]$ and remote sources $[4,13]$. Local sources include underestimated low-level winds [1,11,14-18] and insufficient stratocumulus cloud cover [19-21]. The wind bias results in an SST bias by weakening upwelling in the ABFZ, while the bias in the stratocumulus cloud cover induces an SST bias by enhancing the downward radiative fluxes [8,22]. Cabos et al. [9] and Koseki et al. [11] further linked these local sources to the 
bias in the South Atlantic anticyclone, the intensity of which is underestimated by the atmospheric components of most CCMs. The remote wind biases over the equatorial Atlantic can also affect the SST bias in the ABFZ through Kelvin wave dynamics [13,23]. In addition, Small et al. [12] and Harlaß el al. [10] demonstrated that the warm bias over the ABFZ region can be alleviated by increasing the horizontal and vertical resolutions of the oceanic and atmospheric components of the CCM. Another severe SST bias in the tropical Atlantic is concentrated in the Atlantic cold tongue (ACT) region $\left(10^{\circ} \mathrm{S}-3^{\circ} \mathrm{N}, 20^{\circ} \mathrm{W}-10^{\circ} \mathrm{E}\right)$. Here, to cover the majority of the severe warm bias, the traditional ACT $\left(3^{\circ} \mathrm{S}-3^{\circ} \mathrm{N}, 20^{\circ} \mathrm{W}-0^{\circ} \mathrm{W}\right)$ region is extended eastward to $10^{\circ} \mathrm{E}$ and southward to $10^{\circ} \mathrm{S}$. Most models fail to reproduce the observed ACT during JJA (June-August) [8,24-26]. Instead, these models simulate an SST in the western tropical Atlantic, which is colder than that of the eastern parts, resulting in a reversed zonal SST gradient along the equator [24]. Richter and Xie [24] first reported that the warm SST bias in the ACT is mainly caused by the westerly wind bias along the equator during MAM (March-May). These researchers pointed out that the equatorial easterly winds are underestimated by most of the current atmospheric general circulation models (AGCMs), which is consistent with the results of Chang et al. [27] and Dewitt et al. [28]. The bias in the easterly winds would be further amplified when the AGCM serves as a component of a CCM [28]. The underestimation in the equatorial easterly winds during MAM leads to a deeper thermocline than observed, which inhibits cold tongue development during the next season [29] (JJA). This results in a summertime warm SST bias in the ACT region, which was further confirmed in studies by Chang et al. [30] and Wahl et al. [8].

The present study mainly focuses on the warm SST bias in the ACT region. This could bias the low-level atmospheric circulation simulation, as well as the West African monsoon precipitation [31,32]. Additionally, as models could not capture well the zonal SST gradient, the ability to reproduce the horizontal distribution and variability in monsoonal precipitation is limited [29,31,33,34]. This further limits the capacity of CCMs for seasonal forecasts and projecting future changes in precipitation over West Africa [32,35].

Previous studies have pointed out the leading role of the MAM westerly wind bias in inducing the SST bias over the equatorial Atlantic $[4,5,28,32,36,37]$ based on the results of a multi-model ensemble mean or a CCM. However, these studies mainly focused on the zonal wind bias and rarely considered the effects of biases in other atmospheric forcings. The ACT SST can be directly affected by many different physical processes, including surface net heat flux, zonal advection and vertical processes in the ocean mixed layer [38-40]. These processes depend on the simulated surface zonal winds, surface meridional winds [41], surface specific humidity, surface air temperature, and downward shortwave radiation in the atmosphere [38,39], all of which are forcing data for the ocean components of CCMs. However, all of these forcing data are associated with biases with different spatial patterns and magnitudes (see Section 2.3). The roles of these different biases in inducing SST biases over the ACT region are unknown. In this study, we use an ocean-ice model NEMO to quantify the contribution ratios of biases in different atmospheric forcings (or variables) to the warm ACT SST bias.

This article is organized as follows. The model description, data used, and tropical Atlantic biases of CCM are introduced in Section 2. A set of sensitive experiments is introduced in Section 3. The roles of different atmospheric variables biases in setting up the warm bias over the ACT region and related mechanism are explored in Section 4. Finally, in Section 5, the summary and conclusion are presented.

\section{Data and Methods}

\subsection{Model Description}

The CCM used in this study is Grid-point Version 2 of the Flexible Global Ocean-Atmosphere-Land System (FGOALS-g2), which has been used for decadal projection [42,43] and studying long-term internal variability $[44,45]$. The basic performance of the FGOALS-g2 model was evaluated in the study by Li et al. [46]. This model includes four components (details in Table 1), which are altogether coupled through the coupler CPL6 [47] from NCAR. The atmospheric model has a Gaussian grid of 
$2.8^{\circ}$ between $65.58^{\circ} \mathrm{S}$ and $65.58^{\circ} \mathrm{N}$ and a weighted equal-area grid poleward of $65.58^{\circ}$ with 26 vertical $\sigma$-layers up to $2.194 \mathrm{hPa}$ [48]. The horizontal resolution of the ocean model is $1^{\circ}$ with a meridional refinement to $0.5^{\circ}$ in the tropics. There are 30 vertical layers with a spacing of $10 \mathrm{~m}$ in the upper $150 \mathrm{~m}$, which gradually increased to $700 \mathrm{~m}$ in the deep ocean. The horizontal resolution of the sea ice component is exactly the same as the ocean component $[49,50]$, while that of the land surface component is the same as the atmospheric component. In the tropical Pacific, the model captures well the El Niño-Southern Oscillation (ENSO) [51,52] variability and cloud radiative forcing [53]. However, there are severe warm biases over the ACT region, as most of the CCMs have (detailed in Section 2.3) [4].

Table 1. Detailed information of the FGOALS-g2 model.

\begin{tabular}{|c|c|c|}
\hline Component & Abbreviation & Full Name \\
\hline Atmospheric & GAMIL2 & Grid-Point Atmospheric Model of IAP LASG-Version 2 [45] \\
\hline Ocean & LICOM2 & LASG IAP climate system ocean model Version 2 [54] \\
\hline Land & CLM3 & Community Land Model from the National Center for Atmospheric Research [55] \\
\hline Sea ice & CICE4-LASG & (an improved version of) CICE4.0 (Los Alamos sea ice model Version 4.0) \\
\hline
\end{tabular}

To quantify biases in different atmospheric variables to the warm bias over ACT, we adopt the ocean-ice model, i.ethe version 3.4 of the Nucleus for European Modelling of the Ocean (NEMO v3.4) framework [56] in its global configuration (i.e., ORCA2). This ocean-ice model includes the Océan PArallélisé (OPA) for ocean dynamics and thermodynamics and version 3 of the Louvain-la-neuve Ice Model (LIM3) for the sea ice dynamics and thermodynamics $[57,58]$. The horizontal resolution of this ocean-ice model is $2^{\circ} \times 2^{\circ}$ with a meridional refinement of $0.5^{\circ}$ in the latitudinal bands $5^{\circ} \mathrm{S}-5^{\circ} \mathrm{N}$. There are 31 vertical layers from the surface to $5000 \mathrm{~m}$ with a grid spacing of $10 \mathrm{~m}$ for each layer in the upper $150 \mathrm{~m}$, which gradually increases to an interval of $500 \mathrm{~m}$ in the deep ocean. Input fields of the ocean-ice model include 6-h horizontal winds, air temperature, and humidity at $10 \mathrm{~m}$ height, daily radiation (shortwave and longwave), and monthly total precipitation (rain and snow) and runoff. The default external forcing of the ocean-ice model NEMO v3.4 is from Common Ocean-ice Reference Experiment version II (CORE-II) [59]. Among all the forcings, the atmospheric forcing is the interannual forcing during the period from 1979 to 2005 and the river runoff forcing is 12-month climatology. We interpolate the forcing data to the grid of NEMO v3.4. Note that the river runoff with a salinity value of $0 \mathrm{psu}$ is discharged into the first layer of the grid cell closest to the river mouth.

\subsection{Data}

The CORE-II dataset has been used as observational data when computing the model bias. The CORE-II data was constructed based on National Centers for Environmental Prediction and the National Center for Atmospheric Research (NCEP-NCAR) reanalysis [60] and many high-quality observation datasets. Therefore, compared to NCEP-NCAR and many other reanalysis datasets, CORE-II has a higher reliability and has been used as the forcing data in many ocean-ice models [59].

Data from the historical experiment of FGOALS-g2 is used for the external forcing of the ocean-ice sensitivity experiments. Variables used include the monthly mean surface winds, downward shortwave radiation, surface specific humidity, surface air temperature, and precipitation. In particular, all variables are from the first member of the historical experiment (i.e., r1i1p1).

The data nudged to the climate model FGOALS-g2 is from NCEP-NCAR for the period from 1979 to 2005 (details about the nudging section experiments can be referred to the supplementary materials). Variables used include the 6-h horizontal winds from $1000 \mathrm{hPa}$ to $10 \mathrm{hPa}$.

The observational SST data used is from the Hadley Center Sea Ice and Sea Surface Temperature (HadISST) dataset [61] for the period from 1979 to 2005. The thermocline depth is calculated as the $20^{\circ} \mathrm{C}$ isotherm depth of the climatological mean temperature data from the National Oceanographic Data Center (NODC) World Ocean Atlas (WOA2009) [62]. 


\subsection{Tropical Atlantic Biases of FGOALS-g2}

In this section, we access the performance of FGOALS-g2 for simulating the observed seasonal mean tropical Atlantic climate and compare it with the other twenty CCMs from CMIP5 (details in Table S1). All biases shown in this study are estimated according to the following formula:

$$
\text { Bias }=\overline{\mathrm{A}_{\mathrm{m}}}-\overline{\mathrm{A}_{\mathrm{o}}}
$$

Here, $\mathrm{A}$ is the variable under examination. The subscripts of $\mathrm{m}$ and o denote the model and observation, respectively, and the overbar is the time-mean of a variable.

In this study, the time period of all experiments is from 1979 to 2005. FGOALS-g2 has a severe warm SST bias in the ACT region, which is very similar to that of most CCMs from CMIP5 and to their ensemble means (Figures 1 and S1). The largest value of SST bias from FGOALS-g2 and their ensemble means are $4.63{ }^{\circ} \mathrm{C}$ and $4.43^{\circ} \mathrm{C}$, respectively, over the ACT region during JJA (Table 2). The RMSE of SST from FGOALS-g2 and their ensemble means are $2.25^{\circ} \mathrm{C}$ and $2.38^{\circ} \mathrm{C}$, respectively, over the ACT region during JJA. In addition, the spatial correlation of the SST bias between FGOALS-g2 and the ensemble mean for most of the CMIP5 models is 0.99. Moreover, the largest bias and RMSE of the SST over the ACT region during JJA is comparable to that of all CMIP5 models (Table 2). This indicates that the performance of FGOALS-g2 in the SST simulation is comparable to that of all CMIP5 models (and their ensemble means) in terms of their spatial patterns and magnitudes.
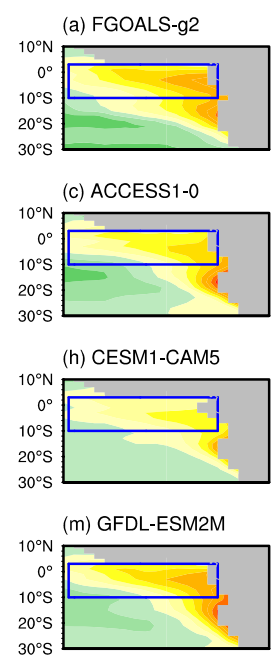

(r) IPSL-CM5A-LR
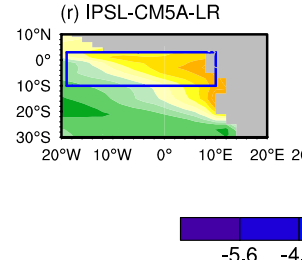

(d) bcc-csm1-1

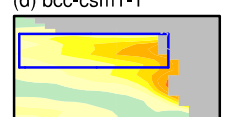

(i) CMCC-CESM

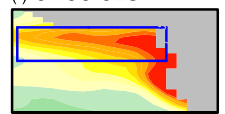

(n) GISS-E2-H

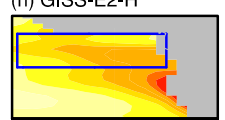

(s) IPSL-CM5A-MR

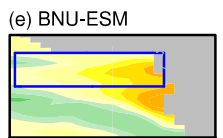

(j) CNRM_CM5

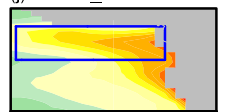

(o) GISS-E2-R

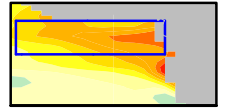

(t) MPI-ESM-LR

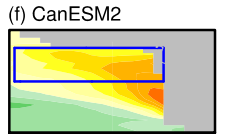

(k) FIO-ESM

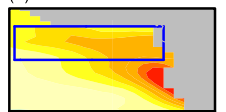

(p) HadCM3

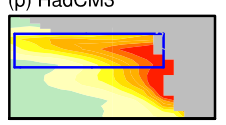

(u) MRI-ESM1

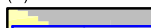

(b) Ensemble_Mean

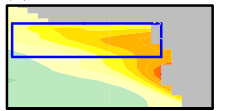

(g) CCSM4

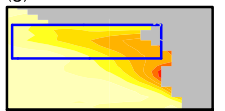

(I) GFDL-CM3

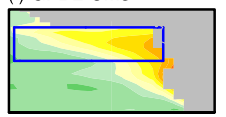

(q) INM-CM4

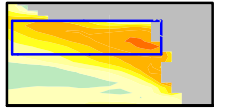

(v) NorESM1-M
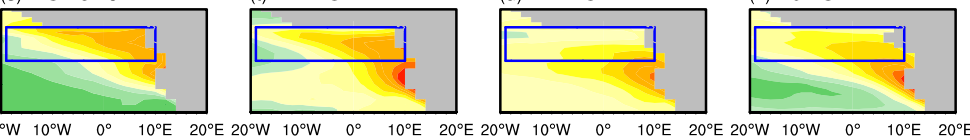

units: ${ }^{\circ} \mathrm{C}$

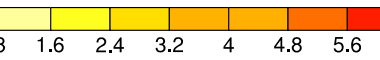

Figure 1. The seasonal mean sea surface temperature (SST; unit: ${ }^{\circ} \mathrm{C}$ ) bias over the southern tropical Atlantic during June-August (JJA) from 1979-2005 for different coupled climate models (CCMs) of CMIP5 and their ensemble means. The blue box denotes the Atlantic Cold Tongue (ACT; $10^{\circ} \mathrm{S}-3^{\circ} \mathrm{N}$, $\left.20^{\circ} \mathrm{W}-10^{\circ} \mathrm{E}\right)$ region.

As for the zonal wind, in the observational data, there are strong prevailing easterly winds along the equator during MAM (Figure 2(a1)). In FGOALS-g2, the equatorial easterly wind is underestimated and associated with a westerly bias (Figure 2(a2,b2)). The westerly bias is distinct during MAM and is mainly concentrated in the western and central parts of the Atlantic equator (Figure 2(a2)). This is similar to the bias in most of the CCMs of CMIP5 (Figure S2) and their ensemble means (Figure 2(a3,b3)). 
There is also a serious northerly wind bias over the ACT region in the FGOALS-g2 model (Figure 2(c2)). In the observations, there are prevailing southerly winds across the equator year-round (Figure 2(c1,d1); not shown during SON and DJF). The northerly bias is more severe during MAM than during JJA (Figure 2(c2,d2)). This meridional wind bias in FGOALS-g2 is similar to that in most of the CCMs of CMIP5 (Figure S3) and similar to their ensemble means (Figure 2(c3,d3)).
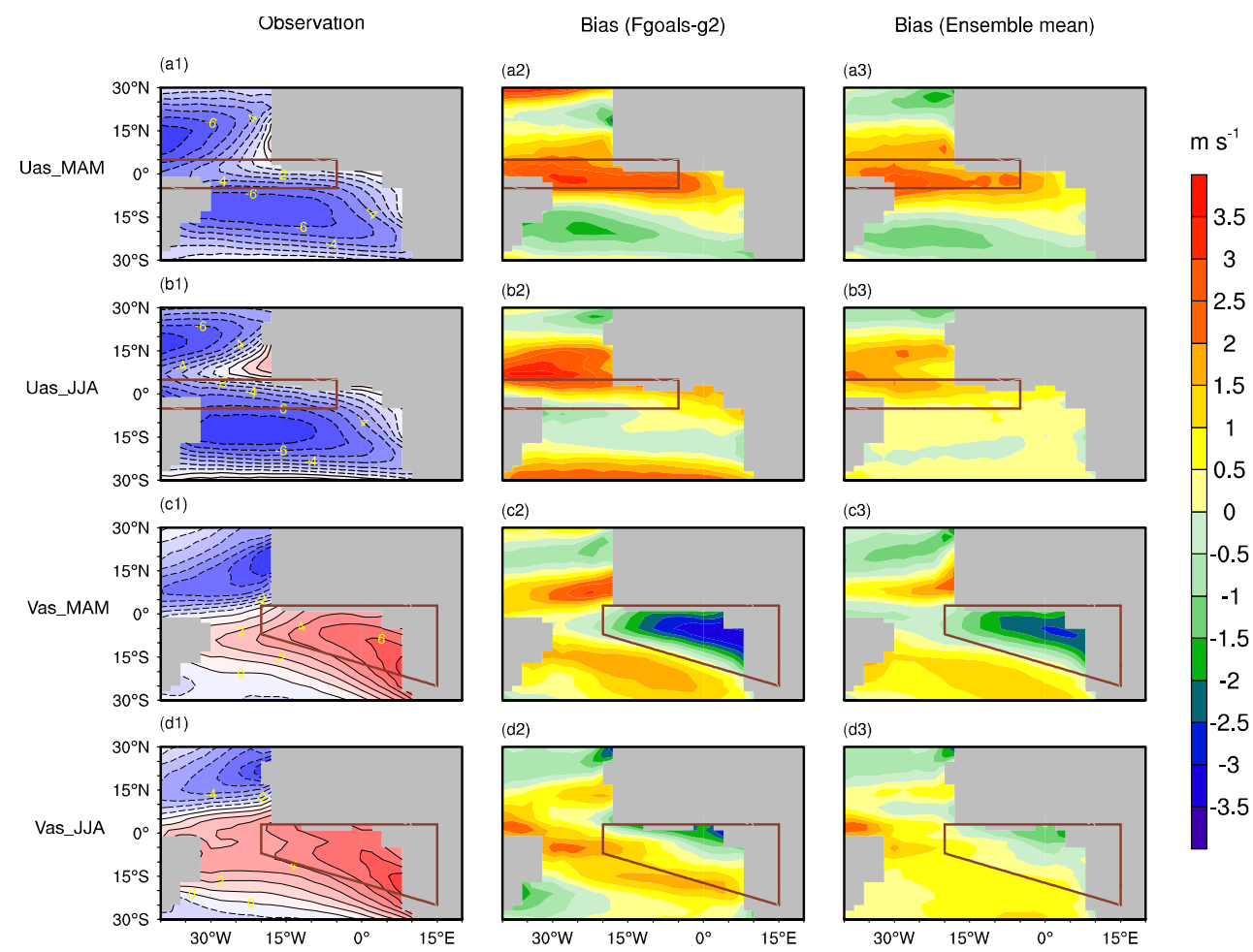

Figure 2. The seasonal mean surface zonal wind (uas; $(\mathbf{a}, \mathbf{b})$; unit: $\mathrm{m} \mathrm{s}^{-1}$ ) and surface meridional wind (vas; (c,d); unit: $\mathrm{m} \mathrm{s}^{-1}$ ) during 1979-2005. Panels (a,c) are for March-May (MAM); (b,d) for JJA. The first column shows the seasonal mean wind in the observational data, the second column shows the seasonal mean wind bias in the FGOALS-g2 model, and the third column shows the seasonal mean bias of the ensemble mean for 21 CCMs in CMIP5. The red box in $(\mathbf{a}, \mathbf{b})$ denotes the equator region, and in $(\mathbf{c}, \mathbf{d})$ denotes the ACT region and the region south of it.

The horizontal distribution of the biases in the surface air temperature and surface specific humidity during JJA over the ACT region mainly follow the SST bias distribution in that area (Figures 1 and 3(a2,b2,a3,b3)). Therefore, similar to the SST bias, the bias in the surface air temperature and surface specific humidity of FGOALS-g2 can also be representative of that for all the twenty CMIP5 models over the ACT region (Figures 3(a2,b2,a3,b3) and 5, S4 and S5).

Over the equatorial Atlantic, there is intense precipitation (Figure 3(c1)). FGOALS-g2 has a large wet bias over the southern equatorial Atlantic and a large dry bias over the northern equatorial Atlantic (Figure 3(c2)). These remarkably large biases are similar to those in other CCMs in the CMIP5 (Figure S6) and their ensemble means (Figure 3(c3)).

FGOALS-g2 also has a large bias in the downward shortwave radiation over the tropical Atlantic (Figures 3(d2) and S7). In the observations, the annual mean shortwave radiations over the ACT region and SETA region are lower than other regions in the tropical Atlantic (Figure 3(d1)). FGOALS-g2 shows a larger positive radiation bias around the SETA region, a smaller positive radiation bias in the ACT region and a negative bias in the western and central equatorial region (Figure 3(d2)). This negative bias may be caused by the positive precipitation bias (corresponding to more clouds). 


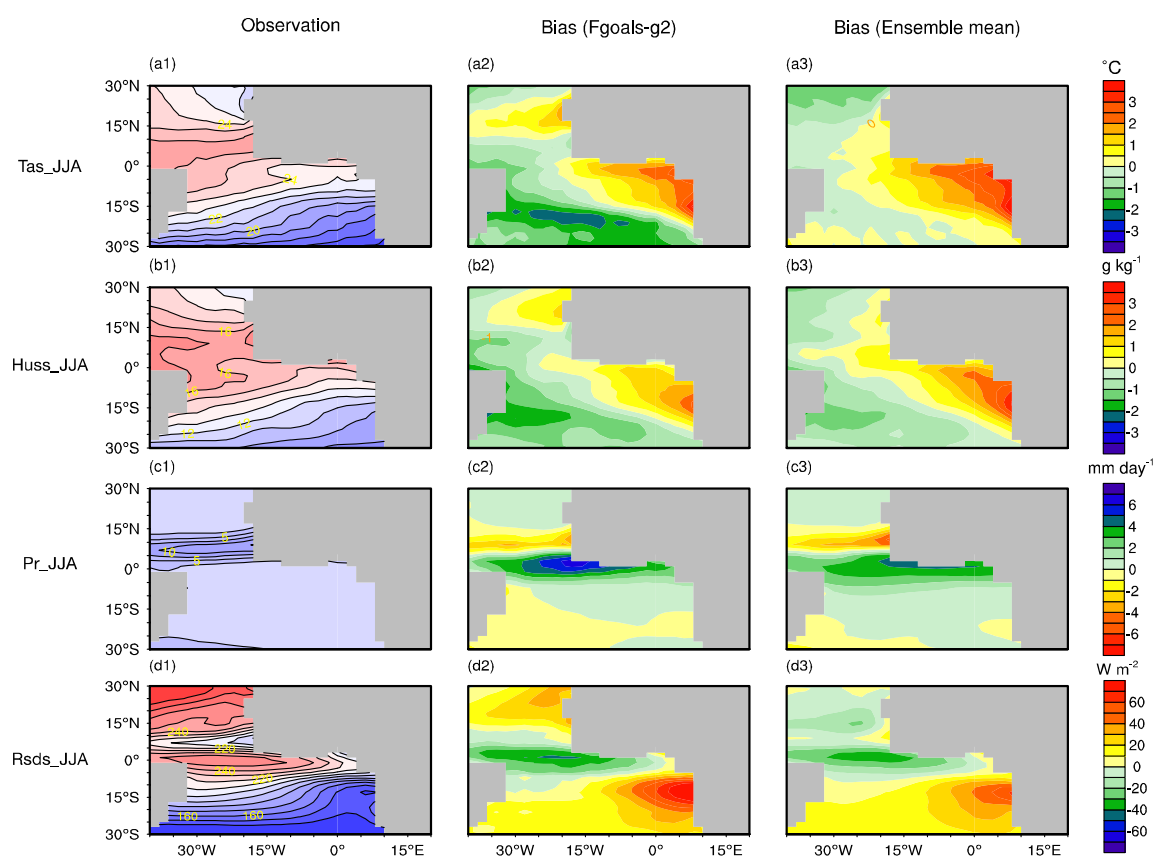

Figure 3. The surface air temperature (tas; (a); unit: $\left.{ }^{\circ} \mathrm{C}\right)$, surface specific humidity (huss; (b); unit: $\mathrm{g} \mathrm{kg}^{-1}$ ), precipitation (pr; (c); unit: $\mathrm{mm} \mathrm{day}^{-1}$ ), and downward shortwave radiation (rsds; (d); unit: $\mathrm{W} \mathrm{m}^{-2}$ ) during JJA of 1979-2005. The first column shows the mean value in the observational data, the second column shows the bias in FGOALS-g2 model, and the third column shows the bias of the ensemble mean of 21 CCMs in CMIP5.

The largest biases and RMSEs of these variables are shown in Table 2. The bias of the forcing data is comparable to that of all twenty CMIP5 models (and their ensemble means) in terms of their spatial patterns and magnitudes. Therefore, it is reasonable to adopt the ocean model NEMO to quantify the contributions of different atmospheric forcing datasets from FGOALS-g2, which has a different ocean component, i.e., LICOM2. In addition, the ocean model NEMO is a widely used ocean general circulation model in the scientific community. Moreover, the ocean model NEMO has been used as the ocean components of a series of coupled climate models in CMIP5. Therefore, studying the SST bias with the NEMO model may benefit the future works using the same ocean model.

Table 2. Detailed information of SSTs and atmospheric forcings for FGOALS-g2, 20 CMIP5 models, and their ensemble means.

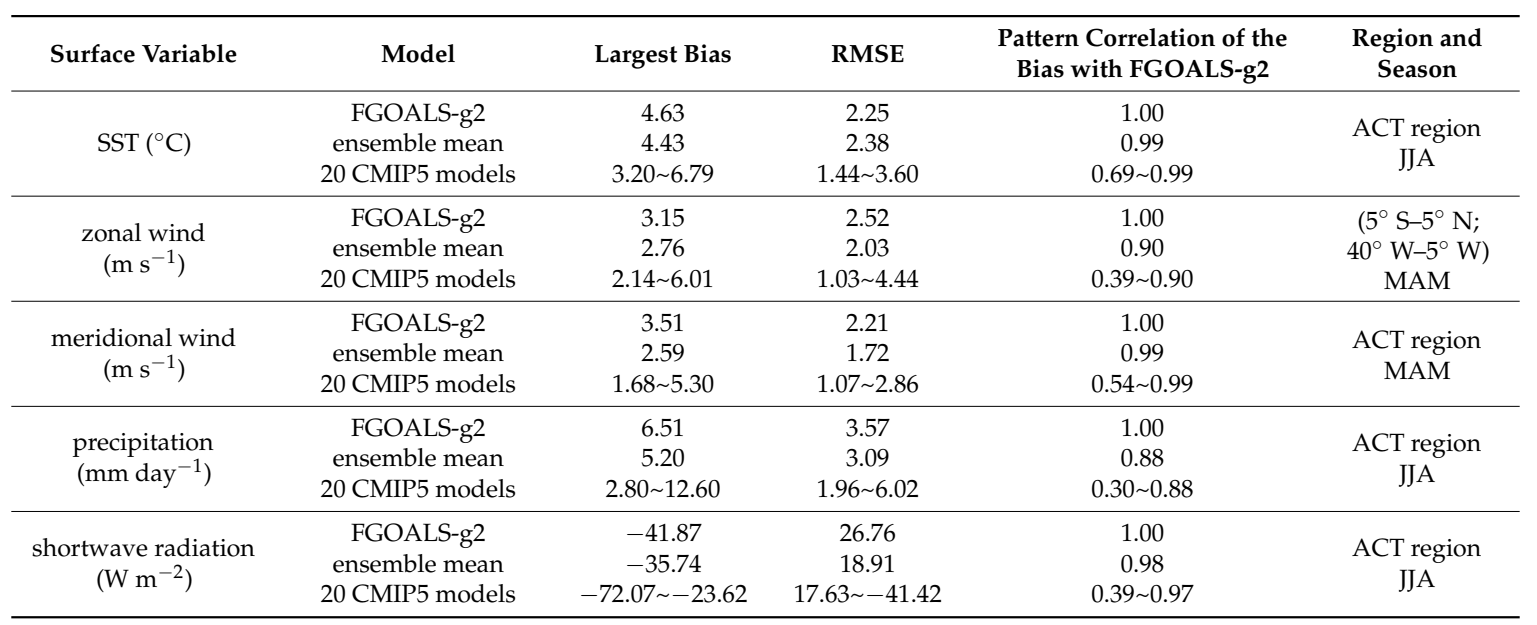




\section{Experimental Design of Ocean-Ice Experiments}

\subsection{Transformation of the FGOALS-g2 Data into Forcing Data for the Ocean-Ice Model}

The atmospheric variables for FGOALS-g2 have a monthly temporal resolution, which is coarser than the corresponding variables of CORE-II (6 h or daily). Following Koseki et al. [11], the variables from FGOALS-g2 are transformed to have the same temporal resolutions as the variables in CORE-II. Here, we take a variable in CORE-II with a daily resolution as an example. A daily variable in CORE-II could be represented as follows:

$$
\mathrm{C}_{\text {daily }}=\overline{\mathrm{C}_{\text {monthly }}}+\mathrm{C}_{\text {daily }}^{\prime}
$$

Here, an overbar denotes the monthly mean of a variable, a prime denotes the corresponding daily deviations, and 'C' denotes the CORE-II forcing. The transformed variable from FGOALS-g2 is computed as follows:

$$
\mathrm{M}_{\text {daily }}=\overline{\mathrm{M}_{\text {monthly }}}+\mathrm{C}_{\text {daily }}^{\prime}
$$

Here, 'M' denotes the monthly variable of the FGOALS-g2. The transformed variable serves as input forcing data for the ocean-ice model. The method for computing the 6-h transformed variable is similar.

In some of the experiments, there are atmospheric forcing variables with two data sources (i.e., a sub-region A with forcing from FGOALS-g2 and the rest region B with forcing from CORE-II) in the spatial dimension. To blend these two types of forcing data spatially, five grid cells (within the

rest region $\mathrm{B}$ ) normal to the spatial boundary between $\mathrm{A}$ and $\mathrm{B}$ are used to build up a buffer region. Taking the daily forcing as an example, the variable of this buffer region is computed as:

$$
\mathrm{M}_{\text {daily }}=\alpha \times \mathrm{M}_{\text {daily }}+(1-\alpha) \times \mathrm{C}_{\text {daily }}
$$

where $\alpha$ is linearly decreased from 1 to 0 in five cells within region B close to the outer boundary of sub-region A.

\subsection{Experimental Design}

To quantify the relative contributions of different atmospheric forcing biases to the warm SST bias in the ACT region, sensitivity experiments are conducted with an ocean-ice model (NEMO v3.4), which is forced by different mixtures of atmospheric forcings from historical FGOALS-g2 and CORE-II datasets. Table 3 gives a detailed description of these experiments.

There are three control experiments in this study: the first is H_CCM, which is the historical experiment of FGOALS-g2 [6]; the second is CTRL_OI, which is an ocean-ice (OI) experiment forced by the atmospheric forcing from the interannual CORE-II dataset; the third is H_All_OI, which is the same as CTRL_OI, except that the atmospheric forcing is from the H_CCM experiment. All three experiments ran from 1979 to 2005. The CTRL_OI experiment is used to evaluate the SST bias that exists in the ocean-ice model, while the H_ALL_OI experiment is conducted to verify the ability of the NEMO v3.4 model in reproducing the mean state and seasonal cycle of the warm SST bias in the southern tropical Atlantic region given by FGOAL S-g2. All experiments based on the NEMO v3.4 model are restarted from the ocean state after a 500-year spin-up experiment from a state of rest with the initial temperature and salinity fields from Levitus94 $[63,64]$, which is forced by the Normal Year CORE-II forcing dataset. 
Table 3. Experiments based on the ocean-ice model NEMO.

\begin{tabular}{|c|c|c|c|c|}
\hline Experiments & Type & Forcing & $\begin{array}{l}\text { Blending Forcing (Only Used in } \\
\text { Monthly Mean Component) }\end{array}$ & Blending Area \\
\hline H_CCM & $\begin{array}{l}\text { Control (Historical } \\
\text { run) }\end{array}$ & - & - & None \\
\hline CTRL_OI & Control & CORE-II & None & None \\
\hline H_All_OI & Control & CORE-II & $\begin{array}{l}10 \mathrm{~m} \text { wind, specific humidity, } \\
\text { air temperature, shortwave } \\
\text { radiation and precipitation }\end{array}$ & Global \\
\hline H_UVQTR_OI & Sensitivity & CORE-II & $\begin{array}{c}10 \mathrm{~m} \text { wind, specific humidity, } \\
\text { air temperature, } \\
\text { shortwave radiation }\end{array}$ & Global \\
\hline H_UVQT_OI & Sensitivity & CORE-II & $\begin{array}{l}10 \mathrm{~m} \text { wind, specific humidity, } \\
\text { air temperature }\end{array}$ & Global \\
\hline H_UV_OI & Sensitivity & CORE-II & $10 \mathrm{~m}$ wind & Global \\
\hline H_U_OI & Sensitivity & CORE-II & $10 \mathrm{~m}$ zonal wind & Global \\
\hline H_V_OI & Sensitivity & CORE-II & $10 \mathrm{~m}$ meridional wind & Global \\
\hline H_U(MAM_Eq)_OI & Sensitivity & CORE-II & $10 \mathrm{~m}$ zonal wind during MAM & $\begin{array}{l}\text { Along the equator } \\
\qquad\left(5^{\circ} \mathrm{S}-5^{\circ} \mathrm{N}\right)\end{array}$ \\
\hline H_V(MAM_STA)_OI & Sensitivity & CORE-II & $10 \mathrm{~m}$ meridional wind during MAM & $\begin{array}{c}\text { Southern tropical } \\
\text { Atlantic } \\
\left(25^{\circ} \mathrm{S}-3^{\circ} \mathrm{N}\right. \\
\left.40^{\circ} \mathrm{W}-20^{\circ} \mathrm{E}\right)\end{array}$ \\
\hline H_V(JJA_STA)_OI & Sensitivity & CORE-II & $10 \mathrm{~m}$ meridional wind during JJA & $\begin{array}{l}\left(25^{\circ} \mathrm{S}-3^{\circ} \mathrm{N}\right. \\
\left.40^{\circ} \mathrm{W}-20^{\circ} \mathrm{E}\right)\end{array}$ \\
\hline H_V(SON_STA)_OI & Sensitivity & CORE-II & $10 \mathrm{~m}$ meridional wind during SON & $\begin{array}{l}\left(25^{\circ} \mathrm{S}-3^{\circ} \mathrm{N}\right. \\
\left.40^{\circ} \mathrm{W}-20^{\circ} \mathrm{E}\right)\end{array}$ \\
\hline H_V(DJF)_OI & CORE-II & CORE-II & $10 \mathrm{~m}$ meridional wind during DJF & $\begin{array}{l}\left(25^{\circ} \mathrm{S}-3^{\circ} \mathrm{N}\right. \\
\left.40^{\circ} \mathrm{W}-20^{\circ} \mathrm{E}\right)\end{array}$ \\
\hline
\end{tabular}

In addition to the three control experiments, a set of sensitivity experiments have been performed using the NEMO v3.4 model to quantify the roles of the biases in different atmospheric variables. All ocean-ice experiments had the same model configuration, but each had different atmospheric forcing data.

These ocean-ice sensitivity experiments can be divided into two types. In the first type, there are five ocean-ice sensitivity experiments used to quantify the relative contributions from the biases in atmospheric variables (i.e., precipitation, downward shortwave radiation, surface specific humidity, surface air temperature, zonal wind, and meridional wind) to the warm SST bias in the ACT region. These five experiments include the following: (1) H_UVQTR_OI, which is the same as H_All_OI except that the precipitation forcing is from the CORE-II dataset and the aim is to examine the role of precipitation bias; (2) H_UVQT_OI, which is the same as H_UVQTR_OI, except that the downward shortwave radiation is from the CORE-II dataset and is used to quantify the role of shortwave radiation bias; (3) H_UV_OI, which is the same as H_UVQT_OI, except that the specific humidity and air temperature are from the CORE-II dataset and is used to assess the combined effects of biases in surface humidity and surface air temperature that may co-vary with each other [65-68]; (4) H_U_OI, which is the same as H_UV_OI except that the meridional wind is from the CORE-II dataset; and (5) H_V_OI, which is the same as H_UV_OI, except that the zonal wind is from the CORE-II dataset. The H_U_OI and H_V_OI experiments are carried out to separately quantify the roles of surface meridional wind and zonal wind. Thus, this type of experiment could compare the relative contribution of the bias in each atmospheric variable to the SST bias in the ACT region. In the names of these experiments, the letters after ' ', denote different atmospheric forcings. Specifically, ' $U$ ' stands for zonal wind, ' $V$ ' for meridional forcing, ' $Q$ ' for specific humidity, ' $T$ ' for air temperature, and ' $\mathrm{R}$ ' for downward shortwave radiation. In addition, the letter ' $\mathrm{H}^{\prime}$ before '_' indicates that the atmospheric forcing after '_' is from the historical run of FGOALS-g2. 'OI' denotes that the experiment is an ocean-ice run. Based on the above 
rule, 'H_UV_OI' means that this experiment is forced by zonal $(\mathrm{U})$ and meridional $(\mathrm{V})$ wind forcings from the historical run of FGOALS-g2 and the other atmospheric forcing from the CORE-II dataset.

The second type of sensitivity experiment also contains five experiments, i.e., H_U(MAM_Eq)_OI, H_V(MAM_STA_STA)_OI, H_V(JJA_STA)_OI, H_V(SON_STA)_OI and H_V(DJF_STA)_OI. Based on the results of the first type of experiment, the bias in the surface wind (zonal and meridional) plays a leading role in the formation of the warm SST bias over the ACT region. The second type of experiment is carried out to quantify the impact of the surface wind bias during different seasons on the SST bias. For the zonal wind, we mainly focus on the bias along the equator $\left(5^{\circ} \mathrm{S}-5^{\circ} \mathrm{N}\right)$ during MAM, since previous studies have pointed out its possible role in inducing the warm bias $[8,24,37]$. In the second type of experiment, the name 'H_U(MAM_Eq)_OI' means that zonal wind (U) forcing during MAM along the equator $\left(\mathrm{Eq} ; 5^{\circ} \mathrm{S}-5^{\circ} \mathrm{N}\right)$ is from the historical $(\mathrm{H})$ run of FGOALS-g2, while the other forcings are from CORE-II. Similarly, the 'H_V(MAM_STA)' means that the meridional wind forcing (V) during MAM over the southern tropical Atlantic (STA; $25^{\circ} \mathrm{S}-3^{\circ} \mathrm{N}, 40^{\circ} \mathrm{W}-20^{\circ} \mathrm{E}$ ) is from the historical $(\mathrm{H})$ run of FGOALS-g2, while the other atmospheric forcings are from CORE-II. Furthermore, 'H_V(JJA_STA)_OI', 'H_V(SON_STA)_OI', and 'H_V(DJF)_OI' are the same as H_V(MAM_STA)_OI, except that the meridional wind forcing $(\mathrm{V})$ from the historical run covers a different season. Notably, 'SON' is for September-November (SON), and 'DJF' is for December-February (DJF).

\subsection{Computing the Contribution Ratio of a Variable Bias}

The contribution ratio of a variable bias to the SST bias is estimated as follows:

$$
\mathrm{R}=\left|\frac{\mathrm{RMSE}_{\mathrm{a}}-\mathrm{RMSE}_{\mathrm{b}}}{\mathrm{RMSE}_{\text {hist }}}\right|
$$

Here, $\mathrm{R}$ is the contribution ratio; RMSE denotes the RMSE of the SST over the ACT region; subscripts $\mathrm{a}$ and $\mathrm{b}$ denote the experiment after changing the atmospheric forcing and the experiment before changing the atmospheric forcing, respectively; and RMSE ${ }_{\text {hist }}$ denotes the RMSE of the SST over the ACT region in the historical FGOALS-g2 run. In addition, the term bracketed by two vertical bars denotes the corresponding absolute value of this term.

\section{Results}

\subsection{Bias in the Control Runs}

The seasonal means of the biases from 1979 to 2005 for the H_CCM experiment in terms of surface winds, downward shortwave radiation, surface specific humidity, surface air temperature, and precipitation over the ACT region are displayed in Figure 4. The ACT SST bias is smaller during DJF and MAM and then rapidly increases and reaches its maximum in JJA (Figure 5a). The westerly bias is mainly concentrated along the equator during MAM and north of the equator during JJA. During SON and DJF, the westerly bias remains around the equator, but with much smaller amplitudes (Figure 4a). The northerly bias is over the ACT region year-round (Figure $4 b$ ) and this bias is strongest during MAM and weakest during JJA (Figure $4 \mathrm{~b}$ ). The biases of the surface specific humidity and surface air temperature over the ACT region are positive during JJA and SON and negative during MAM and DJF (Figure 4c,d). Wet bias (i.e., positive precipitation bias) exists year-round over the ACT region and reaches its peak during MAM and JJA (Figure 4e). In particular, the maxima of this wet bias during MAM and JJA cover the western part of the ACT and the oceans to the west of the ACT. Results from the atmospheric component of the FGOALS-g2 model forced by SST perturbations over the ACT region indicate that the warm bias over the ACT region plays an indispensable role in generating this wet bias (not shown). Similarly, the bias in shortwave radiation over the ACT region is positive during JJA and SON and negative during MAM and DJF. The roles of these atmospheric biases on the ACT SST bias will be discussed in Sections 4.2 and 4.3. 
(a) Uas
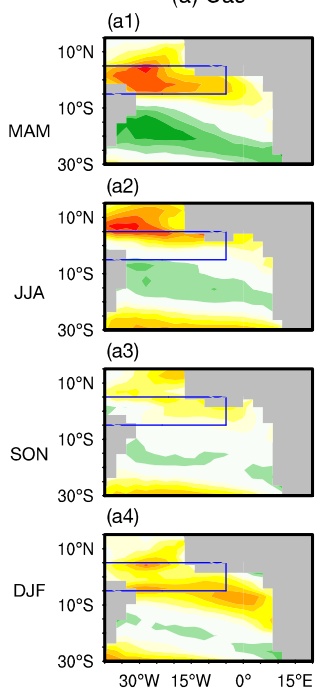

$\mathrm{m} \mathrm{s}^{-1}$ (b) Vas

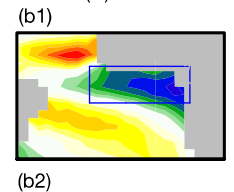

(b2)

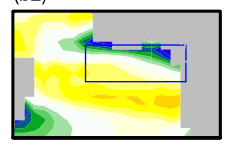

(b3)

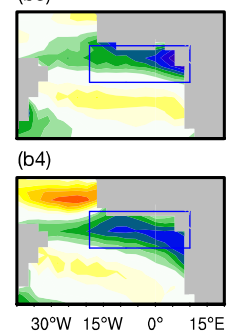

$\mathrm{m} \mathrm{s}^{-1}$ (c) Huss

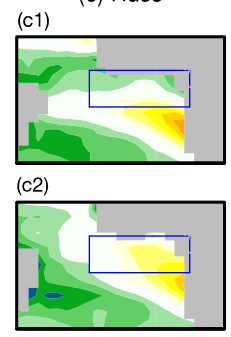

(c3)

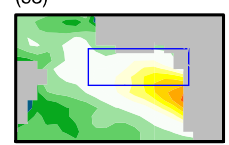

(c4)

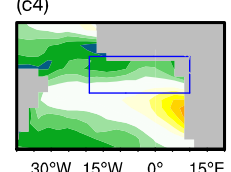

$\mathrm{g} \mathrm{kg}^{-1}$ (d) Tas

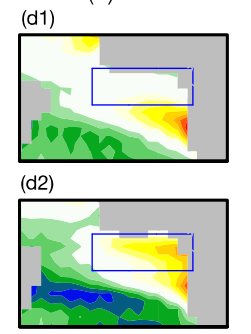

(d3)

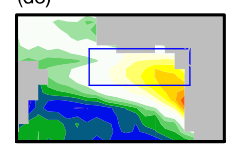

(d4)
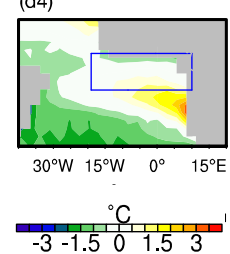

(e) $\operatorname{Pr}$

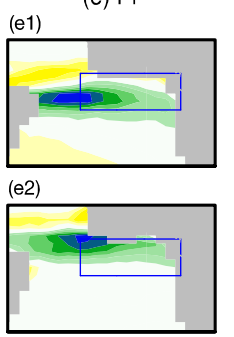

(e3)

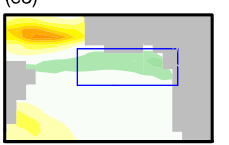

(e4)

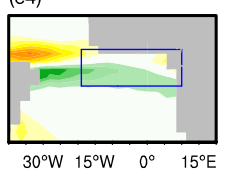

$\mathrm{mm}$ day $^{-1}$ (f) Rsds

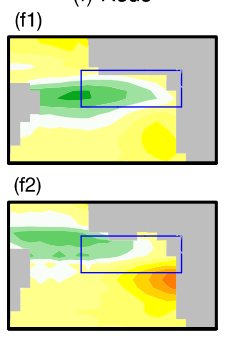

(f3)

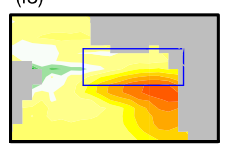

(f4)
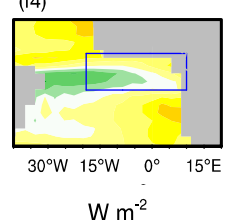

Figure 4. Bias of surface zonal wind (uas; (a); unit: $\mathrm{m} \mathrm{s}^{-1}$ ), surface meridional wind (vas; (b); unit: $\mathrm{m} \mathrm{s}^{-1}$ ), surface specific humidity (huss; (c); unit: $\mathrm{g} \mathrm{kg}^{-1}$ ), surface air temperature (tas; (d); unit: ${ }^{\circ} \mathrm{C}$ ), precipitation (pr; (e); unit: $\mathrm{mm} \mathrm{day}^{-1}$ ), and downward shortwave radiation (rsds; (f); unit: $\mathrm{W} \mathrm{m}^{-2}$ ) in MAM (top), JJA (second row), SON (third row), and DJF (bottom) during 1979-2005 in H_CCM. The blue box denotes the ACT region. Note that the color bar in (e) is reversed.

Next, we assess the SST bias of the control experiment CTRL_OI in the ocean-ice model NEMO v3.4. In the CTRL_OI experiment, we applied restoring conditions for both the SST and sea surface salt (SSS). As a consequence, the seasonal mean and annual mean of the SST biases over the ACT region and SETA region are much smaller (Figures $5 \mathrm{c}$ and $6 \mathrm{c}$ ) relative to the previous studies $[11,18]$. The RMSE of the SST in the ACT region during JJA is $0.82{ }^{\circ} \mathrm{C}$ with the largest value exceeding $1{ }^{\circ} \mathrm{C}$ (Figure 5(c2)) and the RMSE of the SST over the southern tropical Atlantic is $0.56{ }^{\circ} \mathrm{C}$ (Figure $6 \mathrm{c}$ ). A similar experiment, except without any restoring conditions, is conducted to evaluate the impact of the restoring conditions (Figures $5 \mathrm{~d}$ and $6 \mathrm{~d}$ ). In this experiment (No_restore_OI), the RMSE of the SST during JJA is $1.41{ }^{\circ} \mathrm{C}$, with the largest value exceeding $2{ }^{\circ} \mathrm{C}$ in the ACT region (Figure 5(d2)) and the RMSE is $0.94{ }^{\circ} \mathrm{C}$ with the largest value exceeding $1.5^{\circ} \mathrm{C}$ in the southern tropical Atlantic region (Figures 5(d3) and 6d), which is consistent with previous studies [11,18]. It is worth noting that the impacts of the restoring conditions on the SST RMSE during the four seasons are different. The SST RMSEs during MAM, JJA, SON, and DJF in the experiment with restoring conditions (CTRL_OI experiment) are decreased by $0.51^{\circ} \mathrm{C}, 0.59{ }^{\circ} \mathrm{C}, 0.41^{\circ} \mathrm{C}$, and $0.32{ }^{\circ} \mathrm{C}$, respectively (Figure $5 \mathrm{c}, \mathrm{d}$ ), relative to those in the experiment without restoring conditions (No_restore_OI experiment). These differences in SST RMSEs between the two experiments correspond to about $48.6 \%, 15.9 \%, 14.9 \%$, and $35.2 \%$ of the SST RMSEs over the ACT region in the experiment H_CCM during MAM, JJA, SON, and DJF. Therefore, the impacts of the restoring conditions on the SST bias over the ACT region are relatively smaller during JJA and SON compared to the other two seasons, indicating that the use of the restoring conditions in examining the SST bias over the ACT region during JJA and SON will not strongly affect the results. Moreover, the restoring conditions could alleviate the SST bias induced by the oceanic sources, which, in turn, could help us emphasize the impacts of the atmospheric sources. Notably, we applied restoring conditions on the SST and SSS to all the ocean-ice experiments with a restoring time scale of 50 days except the No_restore_OI experiment. 
(a) $\mathrm{H} \_\mathrm{CCM}$
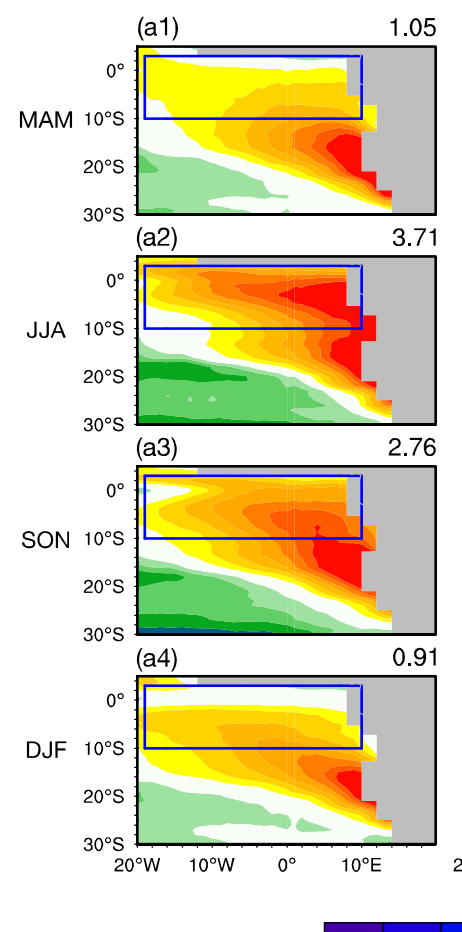

(b) H_All_OI
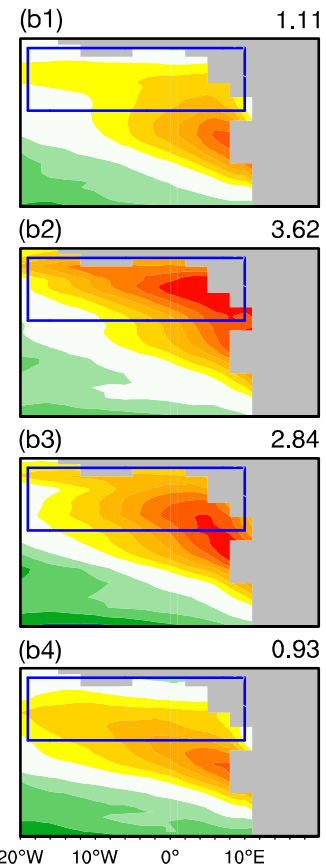

(c) CTRL_OI

(c1)
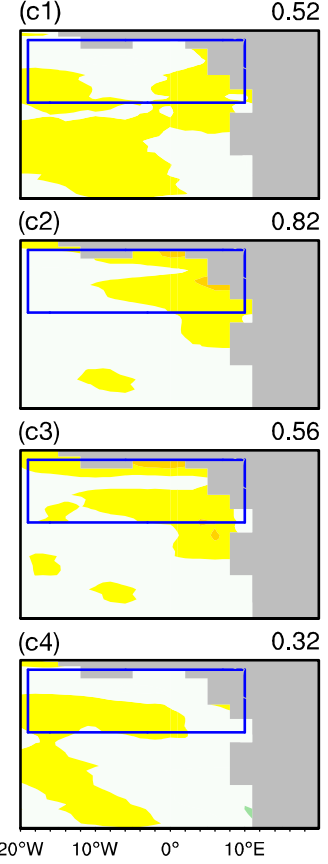

units: ${ }^{\circ} \mathrm{C}$

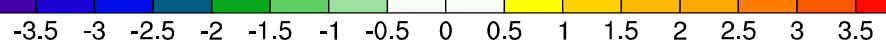

Figure 5. The seasonal mean SST bias (unit: ${ }^{\circ} \mathrm{C}$ ) in MAM (top), JJA (second row), September-November (SON; third row) and December-February (DJF; bottom) during 1979-2005. The first column is for the H_CCM experiment (a); the second for the H_All_OI experiment (b); the third for the CTRL_OI experiment (c); and the fourth for the No_restore_OI experiment (d). The blue box denotes the ACT region. The root mean square error (RMSE) of SST in the box is given on the top right of each panel.

Finally, we evaluate the ability of the NEMO v3.4 model to reproduce the mean state and seasonal cycle of the warm SST bias of FGOALS-g2 over the southern tropical Atlantic region through an ocean-ice experiment forced by the atmosphere forcing from FGOALS-g2 (H_All_OI). H_All_OI has a very similar SST bias as H_CCM in the ACT region (Figure 5a,b) during all four seasons. The RMSE of SST in H_All_OI is $0.09^{\circ} \mathrm{C}$ larger than that in H_CCM over the ACT region (Figure 5a,b). This may be related to the fact that the underestimated shortwave radiation and underestimated surface specific humidity and surface air temperature during MAM and DJF (Figure 4) could lead to a cold bias, which, in turn, increases these biases over the ACT region in H_CCM. By contrast, the above process is lacking in H_All_OI. However, in the SETA region, the SST bias is smaller (Figues 5a,b and 6a,b) in H_All_OI compared to that in H_CCM. This may be because that there is a stratocumulus-SST feedback in H_CCM. Specifically, the overestimated shortwave radiation [69] leads to a warm bias, which in turn results in less stratocumulus (corresponding to more shortwave radiation [69]) over the SETA region in the H_CCM experiment. By contrast, the above feedback process is lacking in H_ALL_OI. 
(a) $\mathrm{H} \_\mathrm{CCM}$

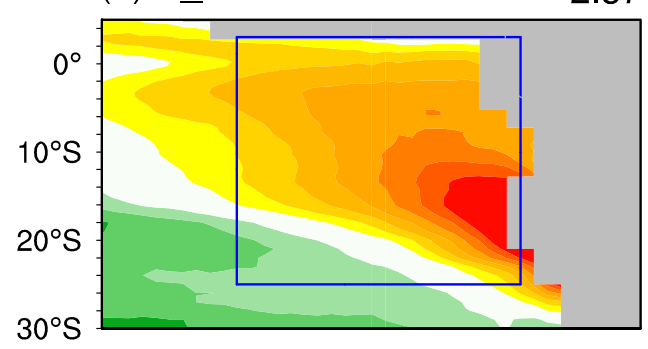

(c) CTRL_OI

2.57 (b) H_All_Ol

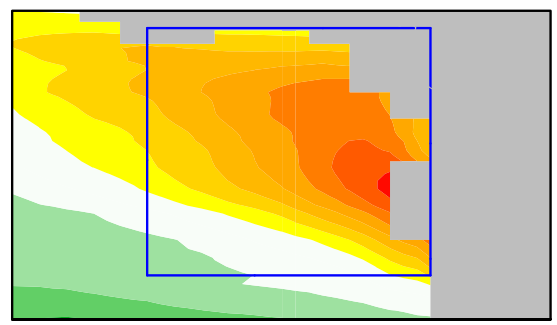

(d) No_restore_OI
2.39

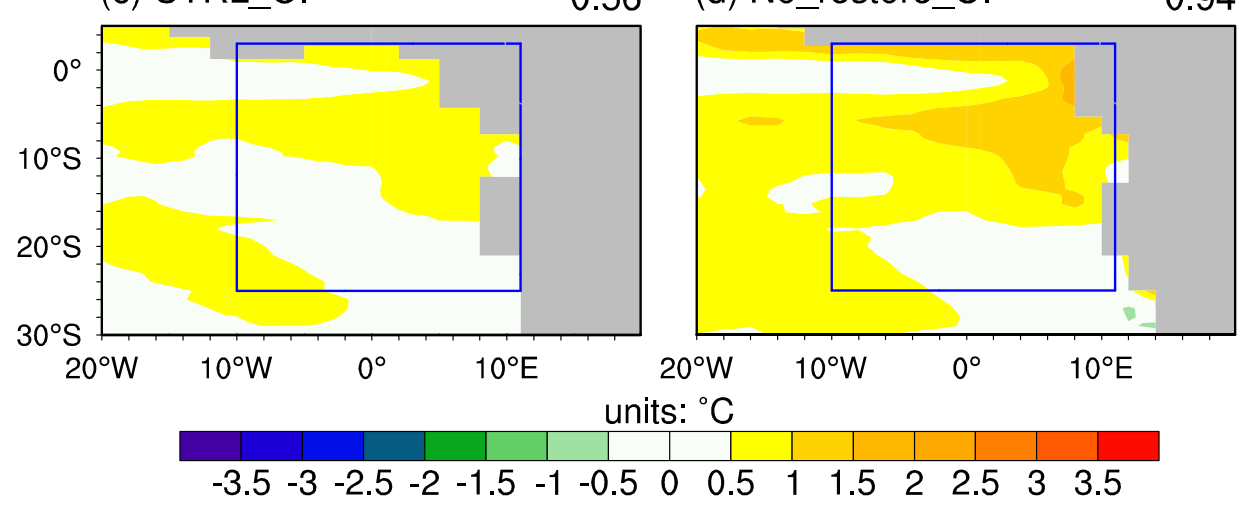

Figure 6. The same as Figure 5 except that it is for the annual mean and the blue box denotes the sub-region $\left(25^{\circ} \mathrm{S}-3^{\circ} \mathrm{N}, 10^{\circ} \mathrm{W}-10^{\circ} \mathrm{E}\right)$ of the Southern Atlantic region.

\subsection{Role of Different Atmospheric Biases}

In this section, we perform sensitivity experiments to quantify the roles of biases in different atmospheric variables in inducing the SST bias in the ACT region. We do this by removing the atmospheric variable bias from the atmospheric forcing for the ocean-ice experiment one by one. Figure 7 shows the seasonal mean SST bias from 1979 to 2005 in the second type of sensitivity experiments over the ACT region. The H_UVQTR_OI experiment is identical to the H_All_OI experiment except that the precipitation forcing is from CORE-II. The warm SST bias in H_UVQTR_OI (Figure 7a) is nearly the same as that in H_All_OI (Figure 5) over the ACT region during all four seasons, with a mean difference of less than $0.1^{\circ} \mathrm{C}$. This indicates that the precipitation bias has a relatively weak impact on the SST bias over the ACT region. This is consistent with Richter et al. [24] who has suggested that the precipitation bias generally induces an SST bias by setting up a westerly wind bias in the CCM. Thus, the nearly unchanged SST bias over the ACT region is reasonable in H_UVQTR_OI, where the zonal wind is from observational data.

As for the role of the bias in the shortwave radiation, we performed an ocean-ice experiment H_UVQT_OI, which is similar to H_UVQTR_OI except that the shortwave radiation is from CORE-II. H_UVQT_OI shows that the absence of a shortwave radiation bias enhances the RMSE of the SST over the ACT region by approximately $0.11^{\circ} \mathrm{C}$ during MAM, approximately $0.03^{\circ} \mathrm{C}$ during DJF and reduces it by $0.24{ }^{\circ} \mathrm{C}$ during JJA and by $0.48^{\circ} \mathrm{C}$ during SON (Figure 7a,b). This indicates that the shortwave radiation bias contributes approximately $6.5 \%$ to the warm SST bias over the ACT region during JJA, approximately $17.4 \%$ during SON and it is not a source of the warm SST bias over the ACT region during MAM and DJF. The reduced SST bias during JJA and SON can be explained by the reduction in the shortwave radiation bias over the ACT region. Moreover, the more the shortwave radiation bias is reduced, the more the warm SST bias is reduced (Figure 4(f2,f3)). Similarly, the enhanced SST bias during MAM and DJF can be explained by the enhancement of the shortwave radiation bias. This also shows that the impact of the shortwave radiation bias on the SST bias over the ACT region is local. 
(a) H_UVQTR_OI
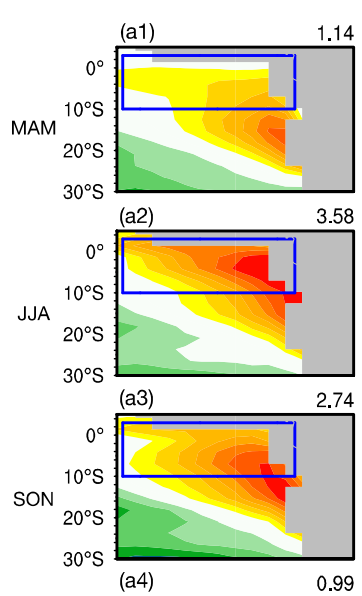

DJF

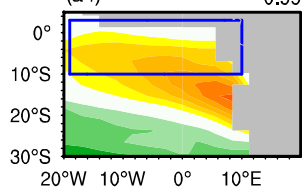

(b) H_UVQT_OI
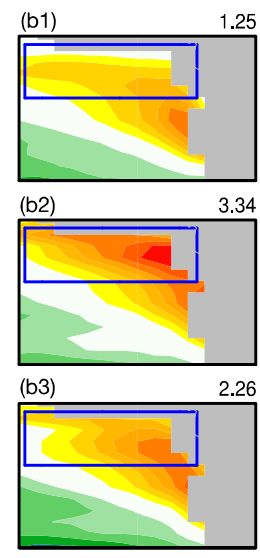

(b4)

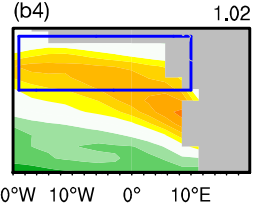

(c) H_UV_Ol
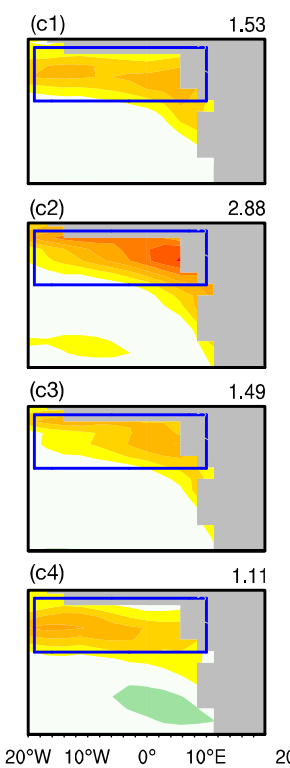

(d) H_U_OI
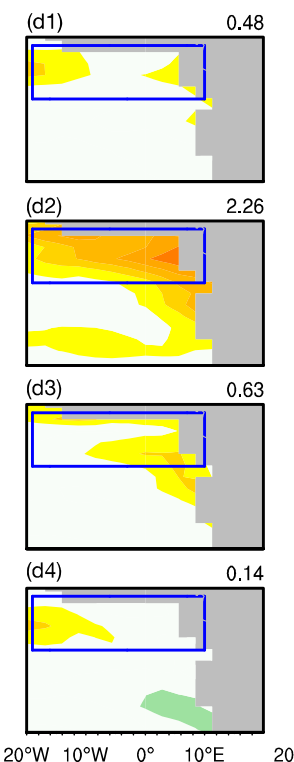

(e) H_V_Ol
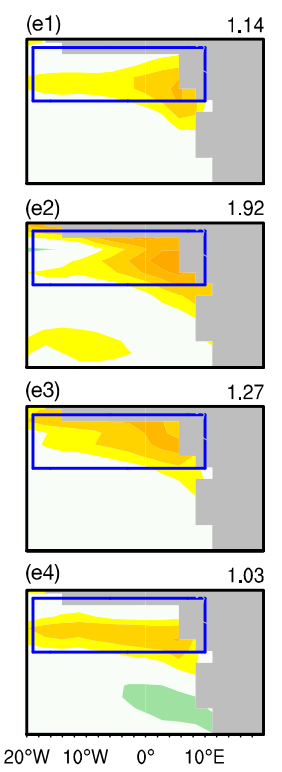

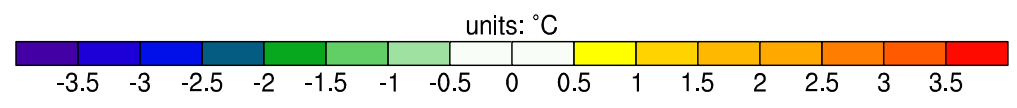

Figure 7. The seasonal mean SST bias (unit: ${ }^{\circ} \mathrm{C}$ ) in MAM (top), JJA (second row), SON (third row), and DJF (bottom) during 1979-2005 in H_UVQTR_OI (a); H_UVQT_OI (b); H_UV_OI (c); H_U_OI (d); and H_V_OI (e). The blue box denotes the ACT region and the area mean of the SST RMSE in the box is given on the top right of the panel.

As for the role of bias in surface specific humidity and air temperature, we perform another ocean-ice experiment (H_UV_OI), which is similar to H_UVQT_OI except that the specific humidity and air temperature forcing is from CORE-II. We remove the biases in both the specific humidity and air temperature from the forcing, as these parameters co-vary with each other and have similar effects on the SST bias $[67,68]$. In H_UV_OI the RMSE of SST over the ACT is enhanced by approximately $0.28^{\circ} \mathrm{C}$ during MAM, $0.09{ }^{\circ} \mathrm{C}$ during DJF, and is reduced by approximately $0.44^{\circ} \mathrm{C}$ during JJA and $0.77^{\circ} \mathrm{C}$ during SON (Figure $7 \mathrm{~b}, \mathrm{c}$ ). This indicates that the bias in the specific humidity and air temperature mainly contributes to the warm SST bias over the ACT region during JJA (approximately $11.9 \%$ ) and SON $(27.9 \%)$, while these parameters have cooling effects on the warm SST bias during MAM and DJF. The reduced SST bias during JJA and SON can be explained by the reduction in the positive bias in the specific humidity and air temperature, which leads to more latent and sensible heat flux out from the sea surface. Moreover, the enhanced SST bias during MAM and DJF can be attributed to the reduction in the negative biases in the specific humidity and air temperature. Furthermore, the effect of the biases in the specific humidity and air temperature on the SST bias are local over the ACT region.

For the bias effects in the surface meridional wind, we perform an ocean-ice experiment (H_U_OI), which is similar to H_UV_OI, except that the meridional wind is from CORE-II. H_U_OI shows that the absence of the meridional wind bias can reduce the warm SST bias over the ACT region in all four seasons. In H_U_OI, the SST RMSE over the ACT region is reduced by approximately $1.05^{\circ} \mathrm{C}$ during MAM, $0.62{ }^{\circ} \mathrm{C}$ during JJA, $0.86{ }^{\circ} \mathrm{C}$ during SON, and $0.97{ }^{\circ} \mathrm{C}$ during DJF (Figure $7 \mathrm{c}, \mathrm{d}$ ). This indicates that the original warm SST bias of FGOALS-g2 over the ACT region during MAM $\left(1.05^{\circ} \mathrm{C}\right)$ and DJF $\left(0.91{ }^{\circ} \mathrm{C}\right)$ is mainly induced by the meridional wind bias, and $16.7 \%$ of that during JJA $\left(3.71^{\circ} \mathrm{C}\right)$ and $31.2 \%$ of that during $\mathrm{SON}\left(2.76{ }^{\circ} \mathrm{C}\right)$ is from the meridional wind bias.

For the role of the bias in the surface zonal wind, we perform an ocean-ice experiment (H_V_OI), which is similar to H_UV_OI except that the zonal forcing is from CORE-II. H_V_OI shows that the absence of the zonal wind bias can reduce the warm SST bias over the ACT region in all four seasons. 
In H_V_OI the absence of the zonal wind bias can reduce the SST RMSE by $0.54{ }^{\circ} \mathrm{C}$ during MAM, $1.36^{\circ} \mathrm{C}$ during JJA, $0.37{ }^{\circ} \mathrm{C}$ during SON, and $0.23^{\circ} \mathrm{C}$ during DJF over the ACT region (Figure $7 \mathrm{c}, \mathrm{e}$ ).

This indicates that the zonal wind bias is one of the sources of the SST bias over the ACT region, and it contributes approximately $51.4 \%$ to the SST bias during MAM, 36.7\% during JJA, $13.4 \%$ during SON and $25.3 \%$ during DJF over the ACT region. This shows that the contribution ratio of the zonal wind bias is the largest among the six atmospheric variables during JJA, which is consistent with previous studies.

The sum of the contribution ratios of zonal wind bias and meridional wind bias to the SST bias over the ACT region during MAM and DJF is larger than 100\%, which is because the precipitation bias, specific humidity and air temperature biases, and shortwave radiation bias have cooling effects on the SST bias over the ACT region during MAM and DJF.

\subsection{Role of the Surface Wind Bias}

The previous subsection shows that both the zonal wind bias and meridional wind bias contribute largely to the warm SST bias over the ACT region year-round. Previous studies have indicated that the leading role of the zonal wind bias during MAM along the equator induces the warm SST bias over the ACT region. In this section, we perform the second type of sensitivity experiment to verify the important role of the zonal wind bias during MAM and further investigate the role of the meridional wind bias during different seasons.

Figure 8 shows the seasonal mean SST bias over the southern tropical Atlantic for all four seasons. To verify the role of the zonal wind bias during MAM along the equator, we perform the H_U(MAM_Eq)_OI experiment, which is similar to the CTRL_OI run, except where the zonal wind forcing during MAM along the equator is from the H_CCM experiment. H_U(MAM_Eq)_OI shows a significant warm SST bias over the ACT region during JJA. This indicates that the westerly bias during MAM along the equator is a main source of the warm bias during JJA over the ACT region and the contribution ratio is approximately $32.6 \%$ (Figure $8 \mathrm{a}$ ). This zonal wind bias enhances the SST bias over the ACT region by $0.17^{\circ} \mathrm{C}$ during MAM, $0.10^{\circ} \mathrm{C}$ during SON, and $0.01{ }^{\circ} \mathrm{C}$ during DJF, which indicates that the zonal wind bias during MAM is not the main source of the warm bias during these three seasons, which is consistent with previous studies. The westerly bias during MAM along the equator enhances the warm bias during JJA and can be explained by the deepening of the thermocline in the ACT region during MAM and JJA (Figure 9a), which has been mentioned in previous studies by Richter et al. [24,37]. The deepening of the thermocline during MAM is accompanied by a warm bias in the subsurface temperature (Figure 10a). The warmer water will then upwell to the sea surface by the prevailing southerly winds, which inhibits the upwelling of the cooling water and results in a warm bias in the sea surface.

As for the meridional wind bias role over the southern tropical Atlantic in inducing the warm SST bias over the ACT region during different seasons, we perform four experiments that are similar to CTRL_OI, except that the meridional wind forcing during different seasons over the southern tropical Atlantic is from the H_CCM experiment. H_V(MAM_STA)_OI shows that the RMSE of SST over the ACT region is enhanced by approximately $0.55{ }^{\circ} \mathrm{C}$ during MAM, $0.34{ }^{\circ} \mathrm{C}$ during JJA, and $0.02{ }^{\circ} \mathrm{C}$ during SON and DJF compared with that of CTRL_OI. This indicates that the northerly bias during MAM over the southern tropical Atlantic mainly contributes to the warm SST bias over the ACT region during MAM (approximately $52.4 \%$ ) and JJA (approximately $9.2 \%$ ), and has a very small effect on the warm bias over the region during SON and DJF. This northerly bias during MAM, which enhanced the warm bias during JJA over the ACT region, can be explained by the deepening of the thermocline as the zonal wind bias does (Figure $9 \mathrm{~b}$ ). The deepening of the thermocline is accompanied by a warm bias in the subsurface temperature (Figure 10b). The warmer water is then upwelled to the sea surface and prevents development of the cold tongue during JJA over the ACT region. Similarly, H_V(JJA_STA)_OI shows an enhanced SST bias only during JJA compared with that of CTRL_OI in the ACT region (Figure 8c), which means that the northerly wind bias during JJA can only contribute to the warm bias 
during JJA (approximately 12.2\%) in the region. This meridional wind bias during JJA also affects the SST bias in that area through deepening of the thermocline and warming of the subsurface temperature during JJA over the ACT region (Figures $9 \mathrm{c}$ and 10c). Moreover, the northerly wind bias during SON (approximately $29.0 \%$ ) and DJF (approximately $81.3 \%$ ) only enhances the SST bias during the same time period (Figure 8d,e). Therefore, only the northerly wind bias during MAM has a delayed effect on the SST bias over the ACT region during the next season (JJA), while that during each of the other seasons could affect the SST bias over the ACT region during the same season.

Furthermore, results from the nudging experiments (Table S2) in the FGOALS-g2 model support the above findings. In the nudging experiments, the zonal wind bias during MAM along the equator plays a leading role in inducing the warm SST bias over the ACT region during JJA with a contribution ratio of approximately $45.6 \%$. Meanwhile, the northerly wind bias during MAM and JJA over the southern tropical Atlantic contributes approximately 32.3\% to the warm SST bias over the ACT region during JJA. In the nudging experiments, the combined effects of the zonal wind bias and meridional wind bias contribute approximately $71.4 \%$ of the warm bias during JJA (Table S3 and Figure S8).

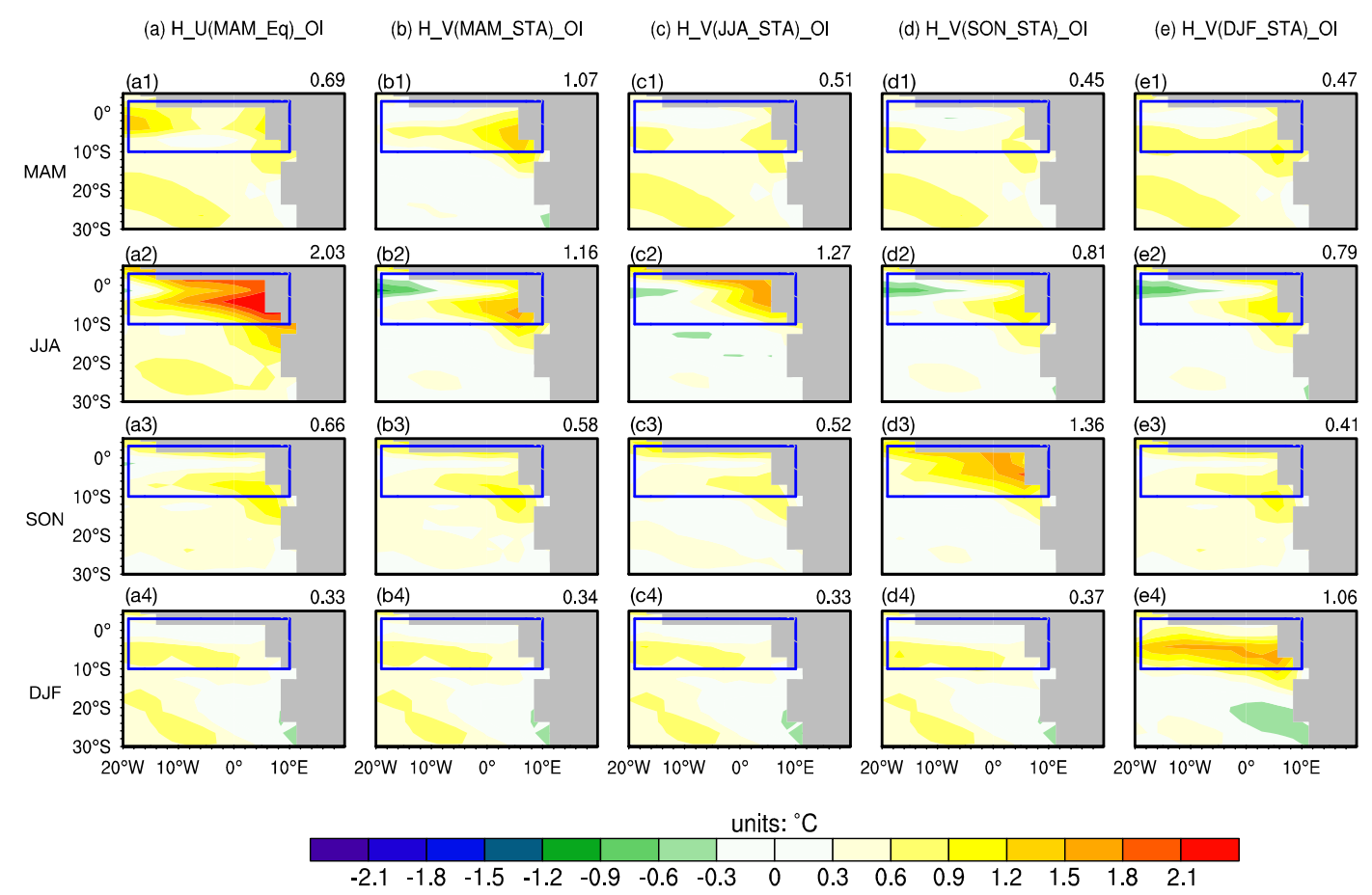

Figure 8. The same as in Figure 7, but for H_U(MAM_Eq)_OI (a); H_V(MAM_STA)_OI (b); H_V(JJA_STA)_OI (c); H_V(SON_STA)_OI (d); and H_V(DJF)_OI (e).

(a) $\mathrm{H}$ U(MAM Eq) OI

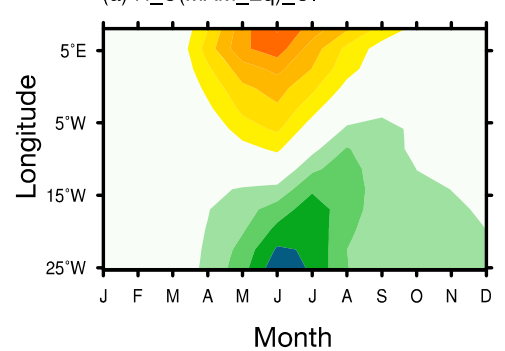

(b) H V(MAM STA) OI

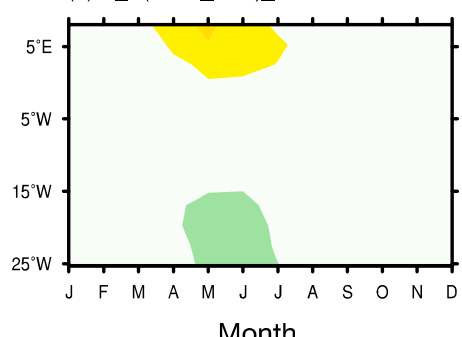

(c) H V(JJA STA) OI

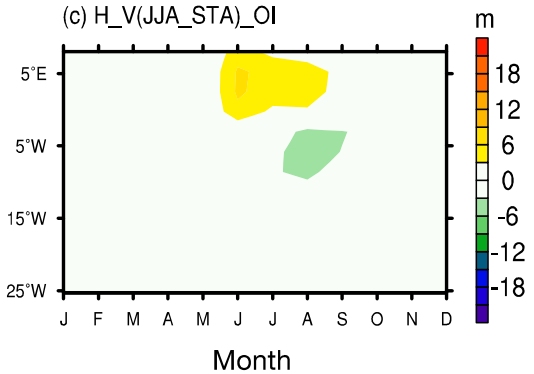

Figure 9. Longitude-month distributions of the bias at the $20{ }^{\circ} \mathrm{C}$ isotherm depth (unit: $\mathrm{m}$, shading) during 1979-2005 for H_U(MAM_Eq)_OI (a); H_V(MAM_STA)_OI (b); and H_V(JJA_STA)_OI (c). 

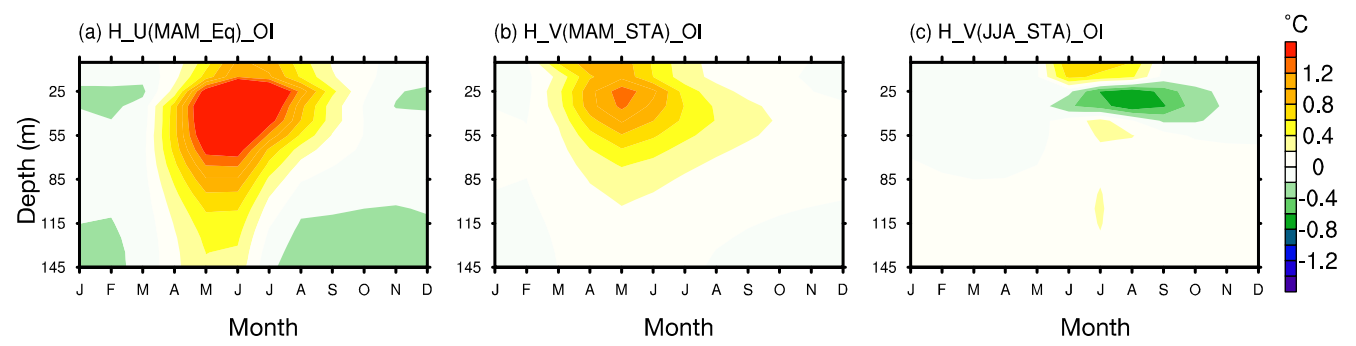

Figure 10. Depth-month distribution of the area-averaged temperature bias (unit: ${ }^{\circ} \mathrm{C}$ ) over the ACT region during 1979-2005 for H_U(MAM_Eq)_OI (a); H_V(MAM_STA)_OI (b);and H_V(JJA_STA)_OI (c).

\section{Summary and Conclusions}

This study quantifies the sources of the warm SST bias over the ACT region in most of the CCMs of CMIP5. This is completed through two types of sensitivity experiments based on an ocean-ice model and the historical simulations of the CCM FGOALS-g2. The FGOALS-g2 model has an SST bias and atmospheric variable bias over the ACT region similar to that of most CMIP5 CCMs. The SST bias during JJA of FGOALS-g2 over the ACT region is the largest, followed by that during SON and the biases during MAM and DJF are much smaller. This is similar to that of most CCMs in CMIP5. The westerly surface wind bias of FGOALS-g2 is mainly concentrated in the central and western equatorial Atlantic during MAM and is relatively weak during the other seasons in that area. The year-round northerly surface wind bias of FGOALS-g2 is mainly concentrated over the southern tropical Atlantic. The bias distributions in the shortwave radiation, surface specific humidity, and surface air temperature are similar to each other over the southern tropical Atlantic, with a positive value during JJA and SON and a negative value during MAM and DJF. In addition, there is a year-round wet bias over the ACT region. All these biases in FGOALS-g2 are similar to that of most CMIP5 CCMs and their ensemble means.

The two types of sensitivity experiments are forced by different mixtures of atmospheric forcings from historical FGOALS-g2 and CORE-II experimental datasets. The analysis based on these experiments confirms that the SST biases over the ACT region are different during all four seasons and the sources of them are different. The largest warm SST bias appears during JJA, which has four main origins, i.e., westerly wind bias during MAM in the western and central equatorial Atlantic $\left(5^{\circ} \mathrm{S}-5^{\circ} \mathrm{N}, 40^{\circ} \mathrm{W}-5^{\circ} \mathrm{W}\right)$, northerly wind bias over the southern tropical Atlantic during MAM and JJA, and positive biases in shortwave radiation, surface specific humidity, and air temperature above the southern tropical Atlantic during JJA. Among these origins, the westerly bias during MAM in the western and central equatorial Atlantic is the most important. It can explain approximately $32.6 \%$ of the ACT warm bias during JJA. This is consistent with the previous study of Richter et al. [16] who had pointed out the leading role of this zonal wind bias. The northerly wind bias during MAM and JJA over the southern tropical Atlantic contributes approximately $21.4 \%$ to the warm bias through both local and non-local effects. The local effect is exerted by the northerly wind bias over the ACT during MAM and JJA through deepening the thermocline and warming the subsurface water during MAM and JJA, which can prevent the development of the cold tongue during JJA over the ACT region and result in a warm SST bias in that area. The non-local effect is exerted by the northerly wind bias off the ACT region through weakening the Angola Current, which can prevent the heat loss of the ACT region and result in a warm SST bias in that area. Moreover, the positive biases in the surface specific humidity and air temperature during JJA over the ACT region contribute approximately $11.9 \%$ to the warm SST bias during JJA over the ACT region through local effects. The overestimated surface specific humidity and air temperature induces SST bias through preventing the latent and sensible heat fluxes from dissipating from the sea surface, which leads to more heat remaining in the sea surface and results in a warm SST bias. It should be noted that the biases in surface specific humidity and air temperature essentially stem from the warm SST bias under examination. Therefore, the impacts of the 
biases in surface specific humidity and air temperature on the warm bias can be viewed as a feedback. Finally, the bias in shortwave radiation during JJA over the ACT region contributes approximately $6.5 \%$ of the warm SST bias during the same season through local effects. Specifically, the positive bias in shortwave radiation over the southeastern part of the ACT region could increase the warm bias, while the negative bias in shortwave radiation over the northwestern part of the ACT region could alleviate the warm bias. However, the combined effects of the biases in shortwave radiation over the two regions increase the warm bias. Following the warm SST bias over the ACT region during JJA, the mean warm SST bias during SON is approximately $2.76{ }^{\circ} \mathrm{C}$ over the ACT region. This bias is mainly from four origins, i.e., northerly wind bias, positive bias in shortwave radiation, surface specific humidity and surface air temperature over the southern tropical Atlantic during SON, and zonal wind bias over the central part of the equatorial Atlantic during SON. Among these origins, the northerly bias during $\mathrm{SON}$ over the ACT region plays a leading role with a contribution ratio of approximately $31.2 \%$. This northerly bias induces a warm SST bias in the region during SON through both local effects (by weakening the upwelling) and non-local effects (by weakening the Angola Current). The positive biases in the surface humidity and surface air temperature during SON over the ACT region contribute approximately $27.9 \%$ of the warm bias during SON through local effects, while the positive bias in the shortwave radiation during the same season contributes approximately $17.4 \%$ through local effects. The zonal wind bias contributes approximately $13.4 \%$ of the warm bias during SON. Furthermore, the warm bias over the ACT region during MAM and DJF is approximately $1{ }^{\circ} \mathrm{C}$. This warm bias is mainly from the northerly bias during the same time period, of which the contribution ratio is larger than $95.0 \%$. It is worth noting that all the above contribution ratios are estimated based on the ocean-ice model NEMO forced by atmospheric forcing from the CCM FGOALS-g2, which means that these ratios may be model-dependent.

The results of our study support the findings by Richter et al. [24,37] that the westerly bias along the equator during MAM (with a contribution ratio of approximately $32.6 \%$ in our study) plays a leading role in inducing the warm bias over the ACT region during JJA. Compared to previous studies, there are new findings in our study. First, results in this study indicate the northerly wind biases over the southern tropical Atlantic during MAM and JJA (with a contribution ratio of approximately $21.4 \%$ ) also play important roles in inducing the warm bias during JJA over the ACT region and the northerly wind bias during SON play a leading role (approximately $31.2 \%$ ) in inducing the warm bias over the ACT region during SON. The northerly wind bias over the southern tropical Atlantic has both local and non-local effects on the warm SST bias over the ACT region. Second, the biases in surface specific humidity and surface air temperature mainly contribute to the warm SST bias over the ACT region during JJA (approximately $11.9 \%$ ) and SON (27.9\%) and have cooling effects on the warm SST bias during MAM and DJF. Moreover, there are feedback processes existing between biases in surface specific humidity and air temperature and the warm bias over the ACT region. Third, the bias in shortwave radiation mainly contributes to the warm SST bias over the ACT region during JJA (approximately 6.5\%) and SON (approximately 17.4\%) and is not a source of the warm SST bias over the ACT region during MAM and DJF. Note that the biases in surface specific humidity, surface air temperature, and shortwave radiation mainly have local effects on the warm SST bias over the ACT region. Fourth, the precipitation bias has a relatively weak impact on the SST bias over the ACT region. Therefore, an atmospheric component with better performance in simulating the zonal winds during MAM over the equatorial Atlantic and meridional winds during MAM, JJA, and SON over the southern tropical Atlantic may be helpful in alleviating the warm bias over the ACT region in the CCM.

There are two limitations in our study. One is that we use an ocean-ice model with a relatively coarse resolution. Small et al. [12], Seo et al. [70], and Zheng et al. [71] attributed the warm SST bias to the low horizontal resolution of the oceanic models. Further, Harlaß el al. [10] pointed out that higher resolution of the atmospheric component in the CCM is also crucial for reducing the warm SST bias over the ACT region. In the future, a high-resolution ocean model should be used to quantify 
the role of atmospheric variable biases in inducing SST biases over the ACT region. Another is that we have isolated the effect of each atmospheric variable bias in this study. However, there exists nonlinear interaction between two or more variables. In the future, the nonlinear interaction of the biases in several variables will be studied and the possible impacts of the nonlinear interaction will be examined.

Supplementary Materials: The following are available online at http:/ /www.mdpi.com/2073-4433/9/7/275/s1, Figure S1: The annual-mean sea surface temperature (SST; units: ${ }^{\circ} \mathrm{C}$ ) bias during 1979-2005 of different coupled climate models (CCMs) in CMIP5 (a and c-v) and their ensemble mean (b) over the southern tropical Atlantic. The blue box denotes the Atlantic cold tongue (ACT; $10^{\circ} \mathrm{S}-3^{\circ} \mathrm{N}, 20^{\circ} \mathrm{W}-10^{\circ} \mathrm{E}$ ) region, Figure S2: The same as Figure $\mathrm{S} 1$ but for the annual-mean surface zonal wind (units: $\mathrm{m} \mathrm{s}^{-1}$ ) bias. The blue box denotes the central and western equatorial Atlantic $\left(5^{\circ} \mathrm{S}-5^{\circ} \mathrm{N}, 40^{\circ} \mathrm{W}-5^{\circ} \mathrm{W}\right)$, Figure S3: The same as Figure S1 but for the annual-mean surface meridional wind (units: $\mathrm{m} \mathrm{s}^{-1}$ ) bias. The blue box includes the ACT and the region south of it, Figure S4: The same as Figure S1 but for the surface air temperature (units: ${ }^{\circ} \mathrm{C}$ ) bias. The blue box includes the ACT region and the southeastern tropical Atlantic (SETA; $25^{\circ} \mathrm{S}-10^{\circ} \mathrm{S}, 10^{\circ} \mathrm{W}-15^{\circ} \mathrm{E}$ ), Figure S5: The same as Figure S1 but for the surface specific humidity (units: $\mathrm{g} \mathrm{kg}^{-1}$ ) bias, Figure S6: The same as Figure S1 but for the precipitation (units: $\mathrm{mm}$ day $^{-1}$ ) bias. Note that, the color bar is reversed compared with that of the figures above, Figure S7: The same as Figure S1 but for the downward shortwave radiation (units: $\mathrm{W} \mathrm{m}^{-2}$ ) bias. The blue box includes the ACT and a part of the SETA region, Figure S8: Seasonal cycle of the SST (units: ${ }^{\circ} \mathrm{C}$ ) over the ACT region during 1979-2005 for HadISST (black dashes line), H_CCM (black solid line), U_MAM_nudg (green solid line), V_MAM_JJA_nudg (blue solid line), and U_V_nudg (red solid line). Table S1: CMIP5 models used in this study, Table S2: Nudging experiments based on the coupled model FGOALS-g2, Table S3: The mean area-averaged SST bias of MAM and JJA over the Atlantic cold tongue (ACT) region $\left(10^{\circ} \mathrm{S}-3^{\circ} \mathrm{N}, 20^{\circ} \mathrm{W}-10^{\circ} \mathrm{E}\right)$ during 1979-2005 for the three nudging experiments based on the FGOALS-g2 model.

Author Contributions: W.H. conceived and designed the study; W.H. and Y.S. analyzed the data and discussed the results; B.W., Z.Y., X.H., and T.Q. discussed the results; and Y.S. and W.H. wrote the paper.

Funding: This research was funded by the National Key Basic Research Program of China (2014CB441302, 2015CB953703) and the National Natural Science Foundation of China (41505063).

Acknowledgments: We thank three anonymous reviewers for comments and suggestions that led to improvement of the manuscript. The NCEP-NCAR reanalysis data is available from https://www.esrl.noaa.gov/psd/data/ gridded/data.ncep.reanalysis.html. The CORE-II dataset is available from http:/ /data1.gfdl.noaa.gov/nomads / forms/core/COREv2.html.

Conflicts of Interest: The authors declare no conflict of interest.

\section{References}

1. Grodsky, S.A.; Carton, J.A.; Nigam, S.; Okumura, Y.M. Tropical Atlantic biases in CCSM4. J. Clim. 2012, 25, 3684-3701. [CrossRef]

2. Huang, B.; Hu, Z.; Jha, B. Evolution of model systematic errors in the tropical Atlantic basin from coupled climate hindcasts. Clim. Dyn. 2007, 28, 661-682. [CrossRef]

3. Li, G.; Xie, S.P. Origins of tropical-wide SST biases in CMIP multi-model ensembles. Geophys. Res. Lett. 2012, 39, 22703. [CrossRef]

4. Richter, I. Climate model biases in the eastern tropical oceans: Causes, impacts and ways forward. Wiley Interdiscip. Rev. Clim. Chang. 2015, 6, 345-358. [CrossRef]

5. Richter, I.; Xie, S.P.; Wittenberg, A.T.; Masumoto, Y. Tropical Atlantic biases and their relation to surface wind stress and terrestrial precipitation. Clim. Dyn. 2011, 38, 985-1001. [CrossRef]

6. Taylor, K.E.; Stouffer, R.J.; Meehl, G.A. An Overview of CMIP5 and the Experiment Design. Bull. Am. Meteorol. Soc. 2012, 93, 485-498. [CrossRef]

7. Toniazzo, T.; Woolnough, S. Development of warm SST errors in the southern tropical Atlantic in CMIP5 decadal hindcasts. Clim. Dyn. 2014, 43, 2889-2913. [CrossRef]

8. Wahl, S.; Latif, M.; Park, W.; Keenlyside, N. On the Tropical Atlantic SST warm bias in the Kiel Climate Model. Clim. Dyn. 2011, 36, 891-906. [CrossRef]

9. Cabos, W.; Sein, D.V.; Pinto, J.G.; Fink, A.H.; Koldunov, N.V.; Alvarez, F.; Izquierdo, A.; Keenlyside, N.; Jacob, D. The South Atlantic Anticyclone as a key player for the representation of the tropical Atlantic climate in coupled climate models. Clim. Dyn. 2017, 48, 4051-4069. [CrossRef] 
10. Harlaß, J.; Latif, M.; Park, W. Alleviating tropical Atlantic sector biases in the Kiel climate model by enhancing horizontal and vertical atmosphere model resolution: Climatology and interannual variability. Clim. Dyn. 2018, 50, 2605-2635. [CrossRef]

11. Koseki, S.; Keenlyside, N.; Demissie, T.; Toniazzo, T.; Counillon, F.; Bethke, I.; Ilicak, M.; Shen, M. Causes of the large warm bias in the Angola-Benguela Frontal Zone in the Norwegian Earth System Model. Clim. Dyn. 2018, 50, 4651-4670. [CrossRef]

12. Small, R.J.; Curchitser, E.; Hedstrom, K.; Kauffman, B.; Large, W.G. The Benguela Upwelling System: Quantifying the Sensitivity to Resolution and Coastal Wind Representation in a Global Climate Model. J. Clim. 2015, 28, 9409-9432. [CrossRef]

13. Lubbecke, J.F.; Boning, C.W.; Keenlyside, N.; Xie, S. On the connection between Benguela and equatorial Atlantic Niños and the role of the South Atlantic Anticyclone. J. Geophys. Res. 2010, 115. [CrossRef]

14. Fennel, W.; Junker, T.; Schmidt, M.A.; Mohrholz, V. Response of the Benguela upwelling systems to spatial variations in the wind stress. Cont. Shelf Res. 2012, 45, 65-77. [CrossRef]

15. Patricola, C.M.; Chang, P. Structure and dynamics of the Benguela low-level coastal jet. Clim. Dyn. 2017, 49, 2765-2788. [CrossRef]

16. Richter, I.; Behera, S.K.; Masumoto, Y.; Taguchi, B.; Komori, N.; Yamagata, T. On the triggering of Benguela Niños: Remote equatorial versus local influences. Geophys. Res. Lett. 2010, 37, 114-122. [CrossRef]

17. Colberg, F.; Reason, C.J.C. A model investigation of internal variability in the Angola Benguela Frontal Zone. J. Geophys. Res. 2007, 112, 112. [CrossRef]

18. Xu, Z.; Chang, P.; Richter, I.; Tang, G. Diagnosing southeast tropical Atlantic SST and ocean circulation biases in the CMIP5 ensemble. Clim. Dyn. 2014, 43, 3123-3145. [CrossRef]

19. Lin, B.; Wielicki, B.A.; Chambers, L.H.; Hu, Y.; Xu, K. The iris hypothesis: A negative or positive cloud feedback? J. Clim. 2002, 15, 3-7. [CrossRef]

20. Miles, T.N.; He, R.; Li, M. Characterizing the South Atlantic Bight seasonal variability and cold-water event in 2003 using a daily cloud-free SST and chlorophyll analysis. Geophys. Res. Lett. 2009, 36, 206-218. [CrossRef]

21. Williams, K.; Webb, M.J. A quantitative performance assessment of cloud regimes in climate models. Clim. Dyn. 2009, 33, 141-157. [CrossRef]

22. Hu, Z.Z.; Huang, B.; Pegion, K. Low cloud errors over the southeastern Atlantic in the NCEP CFS and their association with lower-tropospheric stability and air-sea interaction. J. Geophys. Res. Atmos. $2008,113$. [CrossRef]

23. Florenchie, P.; Lutjeharms, J.R.E.; Reason, C.J.C.; Masson, S.; Rouault, M. The source of Benguela Niños in the South Atlantic Ocean. Geophys. Res. Lett. 2003, 30. [CrossRef]

24. Richter, I.; Xie, S.P. On the origin of equatorial Atlantic biases in coupled general circulation models. Clim. Dyn. 2008, 31, 587-598. [CrossRef]

25. Richter, I.; Xie, S.; Behera, S.K.; Doi, T.; Masumoto, Y. Equatorial Atlantic variability and its relation to mean state biases in CMIP5. Clim. Dyn. 2014, 42, 171-188. [CrossRef]

26. Wang, C.; Zhang, L.; Lee, S.; Wu, L.; Mechoso, C.R. A global perspective on CMIP5 climate model biases. Nat. Clim. Chang. 2014, 4, 201-205. [CrossRef]

27. Chang, C.Y.; Carton, J.A.; Grodsky, S.A.; Nigam, S. Seasonal Climate of the Tropical Atlantic Sector in the NCAR Community Climate System Model 3: Error Structure and Probable Causes of Errors. J. Clim. 2007, 20, 1053-1070. [CrossRef]

28. Dewitt, D.G. Diagnosis of the tropical Atlantic near-equatorial SST bias in a directly coupled atmosphere-ocean general circulation model. Geophys. Res. Lett. 2005, 32, 1737-1738. [CrossRef]

29. Okumura, Y.; Xie, S. Interaction of the Atlantic equatorial cold tongue and the African monsoon. J. Clim. 2004, 17, 3589-3602. [CrossRef]

30. Chang, C.; Nigam, S.; Carton, J.A. Origin of the springtime westerly bias in equatorial Atlantic surface winds in the Community Atmosphere Model version 3 (CAM3) simulation. J. Clim. 2008, 21, 4766-4778. [CrossRef]

31. Meynadier, R.; De Coëtlogon, G.; Leduc-Leballeur, M.; Eymard, L.; Janicot, S. Seasonal influence of the sea surface temperature on the low atmospheric circulation and precipitation in the eastern equatorial Atlantic. Clim. Dyn. 2016, 47, 1127-1142. [CrossRef]

32. Roehrig, R.; Bouniol, D.; Guichard, F.; Hourdin, F.; Redelsperger, J. The Present and Future of the West African Monsoon: A Process-Oriented Assessment of CMIP5 Simulations along the AMMA Transect. J. Clim. 2013, 26, 6471-6505. [CrossRef] 
33. Brandt, P.; Caniaux, G.; Bourles, B.; Lazar, A.; Dengler, M.; Funk, A.; Hormann, V.; Giordani, H.; Marin, F. Equatorial upper-ocean dynamics and their interaction with the West African monsoon. Atmos. Sci. Lett. 2011, 12, 24-30. [CrossRef]

34. Chang, P.; Yamagata, T.; Schopf, P.; Behera, S.K.; Carton, J.; Kessler, W.S.; Meyers, G.; Qu, T.; Schott, F.; Shetye, S.; et al. Climate fluctuations of tropical coupled systems-The role of ocean dynamics. J. Clim. 2006, 19, 5122-5174. [CrossRef]

35. Batté, L.; Déqué, M. Seasonal predictions of precipitation over Africa using coupled ocean-atmosphere general circulation models: Skill of the ENSEMBLES project multimodel ensemble forecasts. Tellus A 2011, 63, 283-299. [CrossRef]

36. Wen, C.; Xue, Y.; Kumar, A. Ocean-Atmosphere Characteristics of Tropical Instability Waves Simulated in the NCEP Climate Forecast System Reanalysis. J. Clim. 2012, 25, 6409-6425. [CrossRef]

37. Ding, H.; Keenlyside, N.; Latif, M.; Park, W.; Wahl, S. The impact of mean state errors on equatorial Atlantic interannual variability in a climate model. J. Geophys. Res. 2015, 120, 1133-1151. [CrossRef]

38. Peter, A.; Henaff, M.L.; Du Penhoat, Y.; Menkes, C.E.; Marin, F.; Vialard, J.; Caniaux, G.; Lazar, A. A model study of the seasonal mixed layer heat budget in the equatorial Atlantic. J. Geophys. Res. 2006, 111. [CrossRef]

39. Huang, W.; Wang, B.; Yu, Y.; Li, L. Improvements in LICOM2. Part I: Vertical Mixing. J. Atmos. Ocean. Technol. 2014, 31, 531-544. [CrossRef]

40. Shi, Y.; Wang, B.; Huang, W. A 'self-adjustment'mechanism for mixed-layer heat budget in the equatorial Atlantic cold tongue. Atmos. Sci. Lett. 2017, 18, 82-87. [CrossRef]

41. Xie, S.P. Oceanic response to the wind forcing associated with the Intertropical Convergence Zone in the northern hemisphere. J. Geophys. Res. Oceans 1994, 99, 20393-20402. [CrossRef]

42. He, Y.; Wang, B.; Liu, M.; Liu, L.; Yu, Y.; Liu, J.; Li, R.; Zhang, C.; Xu, S.; Huang, W. Reduction of initial shock in decadal predictions using a new initialization strategy. Geophys. Res. Lett. 2017, 44, 8538-8547. [CrossRef]

43. Wang, B.; Liu, M.; Yu, Y.; Li, L.; Lin, P.; Dong, L.; Liu, L.; Liu, J.; Huang, W.; Xu, S.; et al. Preliminary evaluations of FGOALS-g2 for decadal predictions. Adv. Atmos. Sci. 2013, 30, 674-683. [CrossRef]

44. Huang, W.; Wang, B.; Li, L.; Dong, L.; Lin, P.; Yu, Y.; Zhou, T.; Liu, L.; Xu, S.; Xia, K.; et al. Variability of atlantic meridional overturning circulation in FGOALS-g2. Adv. Atmos. Sci. 2014, 31, 95-109. [CrossRef]

45. Li, L.; Wang, B.; Dong, L.; Liu, L.; Pu, Y.; Shen, S.; Huang, W.; Sun, W.; Wang, Y.; Shi, X. The Grid-Point Atmospheric Model of IAP LASG-Version 2: GAMIL2. In Flexible Global Ocean-Atmosphere-Land System Model: A Modeling Tool for the Climate Change Research Community; Springer: Berlin/Heidelberg, Germany, 2014; pp. 9-13.

46. Li, L.; Lin, P.; Yu, Y.; Wang, B.; Zhou, T.; Liu, L.; Liu, J.; Bao, Q.; Xu, S.; Huang, W.; et al. The flexible global ocean-atmosphere-land system model, Grid-point Version 2: FGOALS-g2. Adv. Atmos. Sci. 2013, 30, 543-560. [CrossRef]

47. Craig, A.P.; Jacob, R.; Kauffman, B.; Bettge, T.; Larson, J.; Ong, E.; Ding, C.; He, Y. CPL6: The New Extensible, High Performance Parallel Coupler for the Community Climate System Model. Int. J. High Perform. Comput. Appl. 2005, 19, 309-327. [CrossRef]

48. Wang, B.; Wan, H.; Ji, Z.; Zhang, X.; Yu, R.; Yu, Y.; Liu, H. Design of a new dynamical core for global atmospheric models based on some efficient numerical methods. Sci. China Ser. A Math. 2004, 47, 4-21. [CrossRef]

49. Yu, Y.; Zhi, H.; Wang, B.; Wan, H.; Li, C.; Liu, H.; Li, W.; Zheng, W.; Zhou, T. Coupled model simulations of climate changes in the 20th century and beyond. Adv. Atmos. Sci. 2008, 25, 641-654. [CrossRef]

50. Huang, W.; Wang, B.; Li, L.; Yu, Y. Improvements in LICOM2. Part II: Arctic Circulation. J. Atmos. Ocean. Technol. 2014, 31, 233-245. [CrossRef]

51. Bellenger, H.; Guilyardi, É.; Leloup, J.; Lengaigne, M.; Vialard, J. ENSO representation in climate models: From CMIP3 to CMIP5. Clim. Dyn. 2014, 42, 1999-2018. [CrossRef]

52. Kim, S.T.; Cai, W.; Jin, F.; Yu, J. ENSO stability in coupled climate models and its association with mean state. Clim. Dyn. 2014, 42, 3313-3321. [CrossRef]

53. Zhang, Y.; Li, J. Shortwave cloud radiative forcing on major stratus cloud regions in AMIP-type simulations of CMIP3 and CMIP5 models. Adv. Atmos. Sci. 2013, 30, 884-907. [CrossRef] 
54. Liu, H.; Lin, P.; Yu, Y.; Wang, F.; Liu, X.; Zhang, X. LASG/IAP Climate System Ocean Model Version 2: LICOM2. In Flexible Global Ocean-Atmosphere-Land System Model: A Modeling Tool for the Climate Change Research Community; Zhou, T., Yu, Y., Liu, Y., Wang, B., Eds.; Springer: Berlin/Heidelberg, Germany, 2014; pp. 15-26.

55. Oleson, K.; Dai, Y.J.; Bonan, G.B.; Bosilovichm, M.; Dickinson, R.; Dirmeyer, P.; Hoffman, F.; Houser, P.; Levis, S.; Niu, G.Y.; et al. Technical Description of the Community Land Model (CLM); NCAR/TN-461+STR; NCAR: Boulder, CO, USA, 2004.

56. Madec, G.; Delecluse, P.; Imbard, M.; Levy, C. Ocean General Circulation Model Reference Manual; Note du Pôle de Modélisation; LODYC: Paris, France, 1997.

57. Madec, G. NEMO Ocean Engine: Notes du Pole de Modélisation 27; Institut Pierre-Simon Laplace (IPSL): Paris, France, 2008.

58. Vancoppenolle, M.; Bouillon, S.; Fichefet, T.; Goosse, H.; Lecomte, O.; Maqueda, M.M.; Madec, G. LIM The Louvain-la-Neuve Sea Ice Model, Note du Pole de Modélisation; Institut Pierre-Simon Laplace (IPSL): Paris, France, 2012.

59. Large, W.G.; Yeager, S.G. The global climatology of an interannually varying air-sea flux data set. Clim. Dyn. 2009, 33, 341-364. [CrossRef]

60. Kalnay, E.; Kanamitsu, M.; Kistler, R.; Collins, W.; Deaven, D.; Gandin, L.; Iredell, M.; Saha, S.; White, G.; Woollen, J.; et al. The NCEP/NCAR 40-year reanalysis project. Bull. Am. Meteorol. Soc. 1996, 77, 437-471. [CrossRef]

61. Rayner, N.A.; Parker, D.E.; Horton, E.B.; Folland, C.K.; Alexander, L.V.; Rowell, D.P.; Kent, E.C.; Kaplan, A. Global analyses of sea surface temperature, sea ice, and night marine air temperature since the late nineteenth century. J. Geophys. Res. Atmos. 2003, 108. [CrossRef]

62. Conkright, M.E.; Locarnini, R.A.; Garcia, H.E.; O’Brien, T.D.; Boyer, T.P.; Stephens, C.; Antonov, J.I. World Ocean Atlas 2001: Objective Analyses, Data Statistics, and Figures: CD-ROM Documentation; NODC: Washington, DC, USA, 2002.

63. Levitus, S.; Burgett, R.; Boyer, T.P. World Ocean Atlas 1994 Volume 3: Salinity; NOAA Atlas NESDIS 3; NODC: Washington, DC, USA, 1994.

64. Levitus, S.; Boyer, T.P. World Ocean Atlas 1994 Volume 4: Temperature; NOAA Atlas NESDIS 4; NODC: Washington, DC, USA, 1994.

65. Jones, C.; Peterson, P.; Gautier, C. A new method for deriving ocean surface specific humidity and air temperature: An artificial neural network approach. J. Appl. Meteorol. 1999, 38, 1229-1245. [CrossRef]

66. Jourdan, D.; Gautier, C. Comparison between global latent heat flux computed from multisensor (SSM/I and AVHRR) and from in situ data. J. Atmos. Ocean. Technol. 1995, 12, 46-72. [CrossRef]

67. Konda, M.; Imasato, N.; Shibata, A. A new method to determine near-sea surface air temperature by using satellite data. J. Geophys. Res. Oceans 1996, 101, 14349-14360. [CrossRef]

68. Liu, W.T. Statistical relation between monthly mean precipitable water and surface-level humidity over global oceans. Mon. Weather Rev. 1986, 114, 1591-1602. [CrossRef]

69. Zhang, Y.; Chen, Y.; Fan, J.; Leung, L. Application of an Online-Coupled Regional Climate Model, WRF-CAM5, over East Asia for Examination of Ice Nucleation Schemes: Part II. Sensitivity to Heterogeneous Ice Nucleation Parameterizations and Dust Emissions. Climate 2015, 3, 753-774. [CrossRef]

70. Seo, H.; Jochum, M.; Murtugudde, R.; Miller, A.J. Effect of ocean mesoscale variability on the mean state of tropical Atlantic climate. Geophys. Res. Lett. 2006, 33. [CrossRef]

71. Zheng, Y.; Shinoda, T.; Lin, J.; Kiladis, G.N. Sea Surface Temperature Biases under the Stratus Cloud Deck in the Southeast Pacific Ocean in 19 IPCC AR4 Coupled General Circulation Models. J. Clim. 2011, 24, 4139-4164. [CrossRef]

(C) 2018 by the authors. Licensee MDPI, Basel, Switzerland. This article is an open access article distributed under the terms and conditions of the Creative Commons Attribution (CC BY) license (http:/ / creativecommons.org/licenses/by/4.0/). 